\title{
The Euro-Crisis and the Courts: Judicial Review and the Political Process in Comparative Perspective
}

\author{
Federico Fabbrini*
}

INTRODUCTION

Since 2009, the European Union (EU), and especially the member states using the Euro as their currency, has been at the center of a major budgetary, financial, and economic crisis. Because the crisis was triggered and magnified by structural inadequacies of the Economic \& Monetary Union (EMU), the EU institutions and member states reacted by introducing major changes to the EU fiscal constitution - meaning the fundamental norms governing the action of EU institutions and member states in the fiscal domain. ${ }^{1}$ Through a series of legal reforms, the political branches at the national and supranational level have attempted to strengthen the budgetary constraints that guide state fiscal policies, endow the EU with new mechanisms of financial stabilization, and set up a framework for economic adjustment aimed at driving countries in serious economic difficulties out of the crisis through ad hoc programs of assistance. However, the legal measures enacted by the EU institutions and member states to respond to the crisis have increasingly fallen prey to the scrutiny of courts, both at the national and at the supranational level.

The purpose of this Article is to examine how courts have responded to the legal measures adopted by the political branches to tackle the Euro-crisis and to discuss the role of the judiciary in the fiscal domain. To this end, this Article

\footnotetext{
* Assistant Professor of European \& Comparative Constitutional Law, Tilburg Law School, the Netherlands. Earlier versions of this Article were presented at the Conference on "The Constitutionalization of European Budgetary Constraints" (Tilburg, May 2013) and "The European Union and Economic Federalism" (Paris, June 2013). I am in debt to a number of colleagues and friends, including Francesco Costamagna, Alexandre de Streel, Sergio Fabbrini, Michèle Finck, and Anne Meuwese for comments on earlier drafts. All errors remain my own.

1. I am drawing the expression "fiscal constitution" from US constitutional law scholarship and using it here in a broad sense to include the fundamental norms governing policy-making action in budgetary, financial, and economic affairs. See, e.g., David Super, Rethinking Fiscal Federalism, 118 HARVARD L. REV. 2544 (2005).
} 
analyzes a plurality of rulings dealing with various aspects of the new legal architecture of the EMU and delivered in the period from the outburst of the Euro-crisis until the end of 2013. In particular, it considers decisions by high courts in Estonia, France, Germany, Ireland, and Portugal, plus the judgment of the EU Court of Justice (ECJ) in the recent Pringle case, ${ }^{2}$ and seeks to map judicial reactions to the transformations of the constitutional architecture of the EMU. As the Article argues, a trend of increasing judicial involvement in the fiscal domain has emerged throughout Europe as exemplified by the countries considered in this Article. Courts have largely upheld the measures under review, validating the reforms of the EMU introduced by the EU institutions and member states. Nevertheless, over time, courts have also expressed their discomfort with specific aspects of the new EMU fiscal rules, especially those on financial stabilization and economic adjustment-and in some recent cases have even introduced important conditions on the validity of the measures under review or struck them down tout court.

As the Article explains, the main cause for this high degree of judicial intervention in fiscal and economic affairs lies, paradoxically, in the "intergovernmental method" of governance followed in response to the Eurocrisis. ${ }^{3}$ In devising responses to the Euro-crisis, the EU member states have largely operated along an intergovernmental logic, which put at the center the powers of the member states acting in the European Council and their freedom to resort to international agreements outside the EU legal order. One of the central tenets of intergovernmentalism in EU governance is that the executive branches will dominate decision-making, to the detriment of legislatures and courts. Yet, the outcome of an intergovernmental management of the Euro-crisis has resulted, in reality, in an increasing involvement of the courts, in a way that would have been impossible had the member states acted through the "community method." 4 In fact, as this Article highlights, the courts were mainly asked to rule on fiscal issues because the political branches adopted reforms to the EMU architecture via international agreements, which-contrary to EU law - are amenable to domestic judicial review.

2. Case C-370/12, Pringle v. Gov't of Ireland, 2012 E.C.R. I-00000, available at http://curia.europa.eu/juris/document/document.jsf?text=\&docid=130381\&pageIndex $=0 \&$ doclang $=\mathrm{E}$ N\&mode $=1$ st $\&$ dir $=\& o c c=$ first $\&$ part $=1 \&$ cid $=274536$ [hereinafter CJEU Pringle].

3. Following the seminal work of Joseph H.H. Weiler, The Transformation of Europe, 100 YALE L. J. 2403, 2423-24 (1990), I consider as intergovernmental a system of decision-making in which (1) the political impetus for a policy; (2) the technical elaboration of policies and norms; (3) the formulation of a formal proposal; (4) the adoption of the proposal; and (5) the execution of the adopted proposal, is firmly in the hand of the member states.

4. For the paradigmatic definition of the "community method" see Renaud Dehousse, The Community Method at Sixty, in THE Community Method 3 (Renaud Dehousse ed., 2011), defining the "community method" as the default process by which law making is accomplished in the EU, which involves the power of the Commission to propose legislation, the power of the Council-and now, in most of the cases the Parliament-to approve it, and the power of the ECJ to review it. 
As the Article makes clear, the best evidence of how intergovernmentalism produced an unprecedented degree of judicialization in the EMU emerges from a comparative perspective. ${ }^{5}$ Indeed, the role of courts in the fiscal affairs of the EMU far exceeds what one finds even in the country regarded as the example par excellence of a strong system of judicial review: the United States. In the United States, courts have-at least since the 1930s-adopted a deferential position in the economic field, on the understanding that the political process is better placed than the judicial process in answering fundamental budgetary, financial, and economic questions. While, of course, major differences exist between the EU and the United States - notably the fact that the political process is more imperfect in the EU, precisely due to the more intergovernmental and less democratic modes of decision making in the economic domain - the Article suggests that there are still compelling constitutional arguments for why courts in the EMU should also defer to the political branches in the fiscal arena. Because considerations of expertise, voice, and rights plead in favor of letting the political process take the lead in fiscal affairs, this Article critically evaluates the current trend of increasing judicial involvement in the EMU.

Drawing lessons from the analysis of how courts got involved in adjudicating issues related to the new legal architecture of EMU, this Article indicates a strategy for the political branches to minimize future judicial interference, with the threats that this implicates, by adopting legal measures in the framework of EU law. By devising future responses to the Euro-crisis through the community method and EU legislation, therefore, the EU institutions and member states can resort to a procedure that is both more legitimate in democratic terms (because of the political guarantees that surround law making in the EU context) and more secure in judicial terms (because of the more limited space for judicial overreach). Nevertheless - as acknowledged in a recent report by the European Council President entitled "Towards a Genuine EMU" - this Article also emphasizes the shortcomings of the EU political process and concludes by emphasizing that reforms are needed to improve its legitimacy and democracy. As this Article seeks to make clear, criticizing judicial interferences in fiscal affairs and stressing the legitimacy of the ordinary EU law-making procedure in no way implies idealizing it. On the contrary, the legitimacy of the EU political process urgently needs to be improved. However, this should be achieved through greater democratization, rather than greater judicialization.

The Article is structured as follows. Part I provides an overview of the main reforms adopted by the EU institutions and member states to tackle the

5. On the notion of judicialization see notably MARTIN SHAPIRO \& ALEC STONE SwEET, ON LAW, POLITICS AND JUDICIALIZATION 71 (2002), defining judicialization as the process of mutation of the role of the judicial power with its growing capacity to shape strategic behavior of political actors.

6. President of the European Council, Towards a Genuine EMU, report issued June 25, 2012, SN 25/12. 
Euro-crisis and classifies the three main innovations brought about to the constitution of EMU: tighter budgetary constraints, new mechanisms of financial solidarity, and an enhanced framework for economic adjustment. Part II analyzes court decisions and describes in some detail the legal reasoning and substantive outcomes of cases dealing with the new EU fiscal constitution delivered by high courts in Estonia, France, Germany, Ireland, and Portugal, as well as by the ECJ. Part III compares the decisions of courts to identify a rising trend of judicial involvement and explains its cause in the intergovernmental strategy that was followed in response to the Euro-crisis. Here, after a brief excursus on judicial review and the economic constitution in the United States, the Article evaluates the comparative advantages of the political process over the courts in the fiscal domain and considers the avenues that are open to the political branches to devise future responses to the Euro-crisis which are both more democratic and less subject to the whims of the judiciary. Finally, Part IV sketches how future reforms should focus on improving the responsiveness of the EU political process as an alternative to greater judicial involvement in the fiscal arena.

\section{I.}

\section{The New CONSTITUTION OF THE EMU}

Since the outburst of the crisis in 2008-2009, EU institutions and member states have engaged in a major effort to overhaul the architecture of fiscal governance in Europe. As a result, the fiscal constitution of the EMU has been profoundly changed in order to adapt to new circumstances. The constitution of the EMU designed in Maastricht - while setting up a purely federal framework on monetary affairs, ${ }^{7}$ centered on a common currency and the role of the European Central Bank (ECB) to maintain "price stability"8-relied, in fiscal affairs, on mild budgetary constraints, economic policy coordination, and unlimited faith in the capacity of the markets to rein in governmental fiscal mismanagement. ${ }^{9}$ The fiscal constitution that has recently emerged from the responses to the Euro-crisis, on the other hand, is based on three main components. First, the EMU is characterized by tighter budgetary constraints, which subject state budgetary policies to hard domestic limits and pervasive supranational controls. ${ }^{10}$ Second, it is endowed with novel instruments of

7. See generally Stefania Baroncelli, La Banca Centrale Europea: Profili GiURidici e IstituZionali: Un CONFRONTO CON IL MODELlo AMERICANO DELla FederaL RESERVE (2000) (comparing the European Central Bank in the EU and the Federal Reserve System in the United States).

8. See Consolidated Version of the Treaty on the Functioning of the European Union art. 127, Sept. 5, 2008, 2008 O.J. (C115) 47 [hereinafter TFEU].

9. See Ian Harden, The Fiscal Constitution of EMU, in THE LEgal FramewORK OF THE Single EuROPEAN CURRENCY 71 (Paul Beaumont \& Neil Walker eds., 1999).

10. See infra Part I.A. 
financial stabilization, aimed at providing solidarity to countries in economic difficulties and preventing contagious effects in the EMU. ${ }^{11}$ Third, it provides a clear mandate for economic adjustment, introducing powers for the EU institutions to dictate-and, simultaneously, duties for the member states (especially those which receive financial support) to implement-reforms to their economies as a condition for benefitting from transnational aid. ${ }^{12} \mathrm{~A}$ few words will suffice here to describe each of these three features.

\section{A. Budgetary Constraints}

On the assumption that the root causes of the crisis lay in unsustainable public finances, one of the main reforms adopted by both the member states and the EU institutions since 2009 has been the introduction of tighter budgetary constraints aimed at strengthening fiscal discipline and limiting government spending. The objective of ensuring the sustainability of state budgets was already enshrined in the Stability and Growth Pact (SGP) originally enacted in two Council regulations in 1997, ${ }^{13}$ and currently attached as Protocol 12 to the EU Treaties, which requires the member states of the EMU to maintain their public deficit below the yearly ratio of 3 percent of GDP and the total public debt below 60 percent of GDP. ${ }^{14}$ The weaknesses of the enforcement mechanisms of the SGP, however, ensured widespread non-compliance by EMU countries with the SGP debt and deficit criteria. ${ }^{15}$ In response to the failure of the existing legal mechanism, the EU institutions and the member states adopted a two-pronged legal strategy.

On the one hand, several EU legislative acts were enacted to improve the capacity of the EU institutions to supervise and correct budgetary policies of the member states. Pursuant to the so-called "Six Pack" of five regulations and one directive of November $2011,{ }^{16}$ the preventive and corrective limbs of the SGP

11. See infra Part I.B.

12. See infra Part I.C.

13. See Council Regulation 1466/97 of 7 July 1997 on the Strengthening of the Surveillance of Budgetary Positions and the Surveillance and Coordination of Economic Policies, 1997 O.J. (L 209) 1 (second recital); Council Regulation 1467/97 of 7 July 1997 on Speeding Up and Clarifying the Implementation of the Excessive Deficit Procedure, pmbl., 1997 O.J. (L 209) 6 (third recital).

14. See Protocol No. 12 on the Excessive Debt Procedure, 2008 O.J. (C 115) 279.

15. See Stefan Collignon, The End of the Stability and Growth Pact?, 1 INT'L ECON. \& ECON. POL'Y 15, 16 (2004).

16. See Regulation 1173/2011, of the European Parliament and of the Council of 16 November 2011 on the Effective Enforcement of Budgetary Surveillance in the Euro Area, 2011 O.J. (L 306) 1; Regulation 1174/2011, of the European Parliament and of the Council of 16 November 2011 on Enforcement Measures to Correct Excessive Macroeconomic Imbalances in the Euro Area, 2011 O.J. (L 306) 8; Regulation 1175/2011, of the European Parliament and of the Council of 16 November 2011 Amending Council Regulation (EC) No 1466/97 on the Strengthening of the Surveillance of Budgetary Positions and the Surveillance and Coordination of Economic Policies, 2011 O.J. (L 306) 12; Regulation 1176/2011, of the European Parliament and of the Council of 16 November 2011 on the Prevention and Correction of Macroeconomic Imbalances, 
were changed, creating new capacities for the EU Commission to sanction and fine member states for breaches of the deficit and debt rules, as well as establishing a new "macro-economic imbalance procedure" to alert member states of the destabilizing elements of their economies. At the same time, EU law introduced minimum requirements for the design and operation of state budgetary laws, which will be assessed in the framework of the so-called "European semester" in which member states submit their draft budgets to the Commission for compliance with the broader economic forecasts of the EU. Moreover, pursuant to the so-called "Two Pack" of regulations of May 2013, ${ }^{17}$ the Commission's power of surveillance over the budgetary policies of the member states was increased even further, with the ability to object to budget bills drafted by national governments and to require further changes before they are tabled for approval in state parliaments.

On the other hand, new rules were introduced in the domestic legislation of member states to secure balanced budget obligations and internal mechanisms of automatic correction. The Euro-Plus Pact, adopted by the European Council in March 2011, encouraged member states to enhance the sustainability of public finances by translating EU fiscal rules into national legislation. ${ }^{18}$ Nevertheless, it was especially the Treaty on the Stability, Coordination and Governance of the EMU, the so-called Fiscal Compact signed by twenty-five EU Heads of State and Government in March 2012, ${ }^{19}$ that required member states to tighten internal fiscal controls. The Fiscal Compact mandated that signatory parties enact at the state level a balanced budget requirement through provisions of binding force and permanent character, preferably constitutional, or otherwise guaranteed to be fully respected throughout the national budgetary process. ${ }^{20}$ The Fiscal Compact, moreover, empowered the ECJ to review whether member states duly comply with this obligation. ${ }^{21}$ As a result of these pressures, following the German reform of 2009,22 most EU member states have amended

2011 O.J. (L 306) 25; Council Regulation 1177/2011, of 8 November 2011 amending Regulation (EC) No $1467 / 97$ on Speeding Up and Clarifying the Implementation of the Excessive Deficit Procedure, 2011 O.J. (L 306) 33; Council Directive 2011/85/EU of 8 November 2011 on Requirements for Budgetary Frameworks of the Member States, 2011 O.J. (L 306) 41.

17. See Regulation 473/2013 of 21 May 2013 of the European Parliament and the Council on monitoring and assessing draft budgetary plans and ensuring the correction of excessive deficits in euro-area Member States, 2013 O.J. (L 140); Regulation 472/2013 of 21 May 2013 of the European Parliament and the Council on enhanced surveillance of euro-area Member States experiencing or threatened with serious difficulties with respect to their financial stability, 2013 O.J. (L 140).

18. European Council Conclusions, 24/25 Mar. 2011, EUCO 10/1/11, Annex 1, § c.

19. See Treaty on Stability, Coordination and Governance in the Economic and Monetary Union pmbl., art. 16, Mar. 2, 2012, [hereinafter Fiscal Compact], available at http://www .eurozone.europa.eu/media/304649/st00tscg26_en12.pdf (last visited May 10, 2013). On the Fiscal Compact see Paul Craig, The Stability, Coordination and Governance Treaty: Principle, Politics and Pragmatism, 37 Eur. L. Rev. 231 (2012).

20. Fiscal Compact, Art. 3(2).

21. Fiscal Compact, Art. 8.

22. Gesetz zur Anderung des Grundgesetz (Artikel 91c, 91d, 104b, 109, 109a, 115, 143d), 
their domestic constitutions to include a balanced budget requirement, prohibiting structural deficits and the accumulation of excessive debt. ${ }^{23}$ In September 2011, Spain quickly revised Article 135 of its Constitution to ensure that all public administrations would align their actions to the principle of budgetary stability. ${ }^{24}$ Similarly, in April 2012, Italy approved an amendment to Article 81 of its Constitution to tighten the balance between revenues and expenditures and to improve the sustainability of the public debt, ${ }^{25}$ confirming a trend of increasing constitutionalization of European budgetary constraints. ${ }^{26}$

\section{B. Financial Stabilization}

On the understanding that the sovereign debt failure of one Euro-zone country could produce deleterious, contagious effects throughout the EMU, EU institutions and member states have worked in a second direction, devising new legal tools to provide support to states in financial difficulties and thus ensure the stability of the Euro-zone. These mechanisms of financial stabilization represent an entirely new addition to the architecture of the EMU constitution. The original design of the EMU was based on the idea-enshrined in Article 125 of the Treaty of the Functioning of the European Union (TFEU), the socalled "no bail-out clause" 27 - that member states would be solely responsible for the service of their debt and that other EU member states or the ECB would be prohibited from taking up the debt burden of another state. ${ }^{28}$ Nevertheless, the eruption of the Euro-crisis and the complex interconnection between sovereigns and banks revealed that it was actually much easier on paper than in reality to let a country of the Euro-zone default without this producing a

BGBl. I S. 2248 (Nr. 48), 29 July 2009.

23. For more on this see generally Federico Fabbrini, The Fiscal Compact, The 'Golden Rule' and the Paradox of European Federalism, 36 Boston COLLEGE INT'L \& COMP. L. REV. 1 (2013). For a comprehensive comparative examination of the constitutionalization of EU budgetary constraints in the domestic legal systems of the EU member states see THE CONSTITUTIONALIZATION OF EUROPEAN BUdGeTARy CONSTRAints (Maurice Adams, Federico Fabbrini \& Pierre Larouche eds., 2014), which reviews incorporations of balanced budget rules in the domestic systems of, among others, Germany, France, Italy, Spain, Poland, Slovakia, Hungary, Greece, the Netherlands, and Ireland.

24. Reforma del artículo 135 de la Constitución Española, B.O.E. n. 233, 27 Nov. 2011.

25. Legge costituzionale n. 1 del 20.04.2012, G.U.R.I. n. 95, 23 Apr. 2012.

26. See also LB \& JHR, Editorial, The Fiscal Compact and the European Constitutions: “Europe Speaking German,” 8 EUR. CONST. L. REV. 1 (2012).

27. See Article 125 of the TFEU (stating that "[t]he Union shall not be liable for or assume the commitments of central governments, regional, local or other public authorities, other bodies governed by public law, or public undertakings of any Member State.”). See also Article 123 TFEU (stating that "[o]verdraft facilities or any other type of credit facility with the European Central Bank [...] in favour of Union institutions [...]central governments [. . ] shall be prohibited, as shall the purchase directly from them by the European Central Bank or national central banks of debt instruments.").

28. See Matthias Ruffert, The European Debt Crisis and European Union Law, 48 Common MKT. L. REV. 1777 (2011). 
systemic effect on the stability of the Euro-zone as a whole. ${ }^{29}$ Hence, the EU institutions and the member states endowed themselves with new mechanisms to face this challenge. ${ }^{30}$

The legal response proceeded in several steps. In May 2010, the Council of the EU adopted, on the basis of the powers of Article 122(2) TFEU, ${ }^{31}$ a regulation establishing a European Financial Stabilization Mechanism (EFSM) to grant immediate bilateral financial assistance to Greece. ${ }^{32}$ Subsequently, through a private company incorporated under Luxembourg law, the Heads of State and Government of the Euro-zone established a European Financial Stability Facility (EFSF), ${ }^{33}$ charged to operate beyond the short-term emergency which had prompted the creation of the EFSM and effectively providing support to Ireland, Portugal, and (for a second time) Greece. Finally, with the aim to set up a long-term mechanism to stabilize the Euro-zone, and on the assumption that a brand new legal basis was needed in the Treaty to avoid incompatibilities with Article 125 of the TFEU, the twenty-seven EU member states secured through a simplified revision procedure an amendment to Article 136 of the TFEU. This allowed the establishment of a permanent stability mechanism for the EMU. ${ }^{34}$ On this basis, the seventeen Euro-zone countries created a European Stability Mechanism (ESM) through an international treaty. ${ }^{35}$ A first version of the treaty establishing the ESM was concluded in 2011. It was then revised and signed again by the member states of the Euro-zone in February 2012, and it entered into force on September 27, 2012. ${ }^{36}$

The ESM, in particular, is an international institution, modelled on the International Monetary Fund (IMF), ${ }^{37}$ whose purpose is "to mobilise funding

29. See Hannes Hofmeister, To Bail Out or Not to Bail Out? Legal Aspects of the Greek Crisis, 13 CAMBridge YBK. EuR. Leg. ST. 113 (2011).

30. See Phoebus Athanassiou, Of Past Measures and Future Plans for Europe's Exit from the Sovereign Debt Crisis: What is Legally Possible (and What is Not), 36 EuR. L. REV. 558 (2011).

31. See Article 122 of the TFEU (stating that "[w]here a Member State is in difficulties or is seriously threatened with severe difficulties caused by natural disasters or exceptional occurrences beyond its control, the Council, on a proposal from the Commission, may grant, under certain conditions, Union financial assistance to the Member State concerned.").

32. Council Regulation No. 407/2010/EU of 11 May 2010 establishing a European financial stabilisation mechanism, 2010 O.J. (L 118), 1.

33. Decisions of the Representatives of the Government of the Euro Area Member States Meeting within the Council of the EU, ECOFIN, 9.05.2010. Doc. No. 9614/10.

34. Decision No. 2011/199/EU of 25 March 2011, amending Article 136 TFEU with regard to a stability mechanism for Member States whose currency is the euro, 2011 O.J. (L 91) 1.

35. See Treaty Establishing the European Stability Mechanism [hereinafter ESM Treaty], Mar. 25, 2011, available at http://www.european-council.europa.eu/media/582311/05tesm2.en12.pdf (last visited May 10, 2013).

36. On the ESM Treaty see Giulio Napolitano, Il Meccanismo Europeo di Stabilità e la nuova frontiera costituzionale dell'Unione, GIORNALE DI DIRITTO AMMINISTRATIVO 461 (2012).

37. See Jan Wouters \& Thomas Ramopoulos, Time to Reconsider Status: The IMF, the EU, the Euroarea and its Sovereign Debt Crisis (2013) (unpublished manuscript on file with the author). As any international organization, also the ESM enjoys several privileges, including the immunity of 
and provide stability support under strict conditionality, appropriate to the financial assistance instrument chosen, to the benefit of ESM Members which are experiencing, or are threatened by, severe financing problems, if indispensable to safeguard the financial stability of the euro area as a whole and of its Member States." 38 Euro-zone member states contribute to the authorized capital stock of the ESM - totalling 700 billion Euros ${ }^{39}$ - pro-quota on the basis of the subscription by their national central banks to the ECB's capital..$^{40}$ The ESM can grant financial support to a state in need, ${ }^{41}$ provide precautionary financial assistance, ${ }^{42}$ directly (but subject to the existence of a single EU supervisory mechanism) recapitalize banks, ${ }^{43}$ grant loans, ${ }^{44}$ and purchase government bonds on the primary and secondary market. ${ }^{45}$ Decisions about the ESM are mainly made by the Board of Governors - consisting of the Ministries of Finance of the Euro-zone member states - on the basis of unanimity rule. Nevertheless, pursuant to Article 4(4), "an emergency voting procedure shall be used where the Commission and the ECB both conclude that a failure to urgently adopt a decision to grant or implement financial assistance [...] would threaten the economic and financial sustainability of the euro area." In this case, a decision requires only a qualified majority of 85 percent of the votes cast, calculated on the basis of the contributing shares to the ESM capital. Any dispute involving the ESM Treaty can, however, be subject to adjudication before the ECJ ${ }^{46}$ thus contributing to the constitutional anchoring of the ESM to the EU institutional regime. ${ }^{47}$

\section{Economic Adjustment}

The introduction of mechanisms of financial assistance and the possibility for member states facing financial difficulties to receive aid from the EU and its member states, however, did not come free. A third important component of the new constitution of EMU emerging from the Euro-crisis is the introduction of the principle of conditionality as the counterweight to increasing financial solidarity. ${ }^{48}$ Pursuant to this criterion, Euro-zone member states that obtain

persons (ESM Treaty art. 35), the inviolability of the premises (ESM Treaty art. 32) and the privilege of professional secrecy (ESM Treaty art. 34).

38. ESM Treaty art. 3.

39. ESM Treaty art. 8 .

40. ESM Treaty art. $11 \&$ Annex 1.

41. ESM Treaty art. 13.

42. ESM Treaty art. 14.

43. ESM Treaty art. 15.

44. ESM Treaty art. 16.

45. ESM Treaty arts. $17 \& 18$.

46. ESM Treaty art. 37.

47. Otherwise, pursuant to ESM Treaty art. 44, any new state of the EU who adopts the Euro as its currency shall become a member to the ESM by ratifying its founding Treaty.

48. See Vestert Borger, How the Debt Crisis Exposes the Development of Solidarity in the 
financial aid to address a situation of quasi-default are not only required to enact tight budgetary constraints (as any other country of the EU), ${ }^{49}$ but are also subject to specific economic adjustment programs designed to reform the fundamentals of their economy and address structural weaknesses in their domestic systems in areas as far ranging as the flexibility of the labor market, the effectiveness of tax collection, the size and organization of the public administration, the nature and degree of social entitlements, and the characteristics of the banking sector. ${ }^{50}$ The last component of the legal response to the Euro-crisis designed in EU legislation and treaties, therefore, comprises a set of measures whereby the EU institutions (mostly together with the IMF) are empowered to elaborate country-specific programs of economic adjustments and member states contractually agree to implement them within their domestic regimes under supranational supervision..$^{51}$

Besides Article 5(2) of the Fiscal Compact, which foresees the possibility of adopting an economic partnership program, the ESM Treaty now codifies the general legal template for the negotiation of a program of economic adjustment. ${ }^{52}$ Pursuant to Article 13(3), if the ESM Board of Governors decides to grant assistance to a Euro-zone member state, it shall entrust the European Commission -in liaison with the ECB and, wherever possible, together with the IMF-with the task of negotiating, with the ESM Member concerned, a memorandum of understanding (an 'MoU') detailing the conditionality attached to the financial assistance facility. The content of the MoU shall reflect the severity of the weaknesses to be addressed and the financial assistance instrument chosen.

As the MoUs signed by Greece, Portugal, Ireland, Spain, and now Cyprus make clear, these instruments constitute a binding road map that member states receiving financial assistance must respect in order to continue obtaining financial assistance. ${ }^{53}$ The MoU shall be fully consistent with the measures of economic policy coordination provided for in the TFEU, in particular with any act of EU law, including any opinion, warning, recommendation or decision addressed to the state concerned. ${ }^{54}$ At the same time, the EU Commission, the $\mathrm{ECB}$ and the IMF - the so-called "troika"-are empowered to constantly

Euro Area, 9 EUR. CONST. L. REV. 7 (2013).

49. See supra Part I.A.

50. See Damian Chalmers, The European Redistributive State and a European Law of Struggle, 18 E. L. J. 667 (2012) (emphasizing capacity of the EU institutions to dictate to member states policy reforms in a broad range of fields).

51. See Euro Summit, Statement, Oct. 26, 2011 (outlining policies that states must adopt to tackle the crisis).

52. See supra Part I.B.

53. See, e.g., Greece: Memorandum of Understanding on Specific Economic Policy Conditionality, May 3, 2010 available at: http://www.minfin.gr/content-api /f/binaryChannel/minfin/ datastore/a8/52/57/a85257bc11624aa0a2f89a6bebea2219687ce5f0/application/pdf/EU\%2BBundle2. pdf (last visited May 10, 2013).

54. ESM Treaty Art. 13(3). 
monitor progress by the state under an assistance program and demand the adoption of new policies aimed at reaching the agreed goals..$^{55}$

Economic adjustment programs are carried out domestically by national governments and legislatures through appropriate legislation. Nevertheless, as Kenneth Armstrong has underlined:

[f]or those Eurozone states that have received financial support to stabilize their economies, the degree and manner of the constraint on their policy autonomy is significantly heightened. Indeed, the regular mechanisms of accountability and governance are typically suspended for such states which are subject instead to the discipline imposed via $[\mathrm{MoU}]$ and controls exercised in the context of 'macroeconomic adjustment programmes.' ${ }^{56}$

In sum, a relevant component of the new EMU fiscal constitution consists of novel competences for the EU institutions to dictate comprehensive adjustment programs. To address the crisis, states receiving financial support are mandated to implement domestically these programs - which often include a profound restructuring of the welfare state system. ${ }^{57}$

II.

\section{THE NEW CONSTITUTION OF EMU UNDER JUDICIAL SCRUTINY}

The previous section summarized how EU institutions and member states responded to the Euro-crisis and explained the main features of the new constitutional architecture of the EMU. This section explores how courts have responded to the new fiscal rules of the EMU and resolved challenges on the legality of various features of the new legal measures of budgetary constraints, financial stabilization, and economic adjustment. Courts interact with the new EMU fiscal rules in at least two circumstances. On the one hand, judicial bodies are often required to approve ex ante the adoption of legal instruments that contain new fiscal obligations. In many state jurisdictions, the ratification of international treaties such as the Fiscal Compact or the ESM, is subject to prior judicial review by national high courts. ${ }^{58}$ At the same time, both national and supranational courts can be asked whether legislation enacted in the field of EMU is consistent with domestic constitutional norms or with general principles of EU law. ${ }^{59}$ On the other hand, judicial bodies are vested with powers ex post,

55. ESM Treaty Art. 13(7).

56. Kenneth Armstrong, Towards a 'Genuine' Economic \& Monetary Union: The New Governance of Fiscal Discipline (2013) 35 (unpublished manuscript on file with author).

57. See Klaus Bush et al., Euro Crisis, Austerity Policy and the European Social Model: How Crisis in Southern Europe Threatens the EU's Social Dimension, Friederich Ebert Stiftung International Policy Analysis (2013) (discussing the threat that austerity policies produce on the welfare state).

58. See, e.g., 1958 Const., art. 54 (Fr.) (stating that if the French Constitutional Council declares a provisions of an international treaty incompatible with the Constitution, ratification can only be undertaken after amending the Constitution itself).

59. See, e.g., TEU art. 267 (stating that the ECJ shall have the power to give preliminary 
that is, after the establishment of new fiscal rules. In almost all EU member states, and in the EU legal order, courts can review legislation and are thus required to take into account new fiscal commitments and balance them with other, competing constitutional values. ${ }^{60}$ Moreover, since the introduction of constitutional balanced budget obligations, courts can be asked to review whether national governments have complied with new budgetary constraints. ${ }^{61}$

In what follows I will attempt to map early decisions by European courts dealing with the new fiscal constitution of the EMU. To this end, I examine rulings by high courts in Estonia, France, Germany, Ireland, Portugal, and the EU. Besides several pragmatic factors, ${ }^{62}$ the following methodological considerations justify choosing these six case studies as test cases to examine the role of courts in the Euro-crisis. ${ }^{63}$ Taken together, these case studies-and especially the five member states chosen-provide a comprehensive picture of the plurality of political, economic, and legal conditions characterizing the EU. In political terms, France and Germany are founding members of the EU, while Portugal and Ireland joined in the enlargements of the 1970s and 1980s and Estonia is a new member since $2005 .{ }^{64}$ In economic terms, France and Germany (the two biggest economies of the Euro-zone) are net contributors to the EU financial stabilization regime, ${ }^{65}$ as is Estonia (which has however a tiny economy), while Portugal and Ireland are two states under financial assistance programs. In legal terms, finally, France and Germany are jurisdictions with ad

rulings concerning the validity and interpretation of acts adopted by the EU institutions).

60. See, e.g., Donald P. Kommers \& Russell A. Miller, Das Bundesverfassungsgericht: Procedure, Practice and Policy of the German Federal Constitutional Court, 3 J. CoMP. L. 194 (2008) (discussing judicial review in Germany); Federico Fabbrini, Kelsen in Paris: France's Constitutional Reform and the Introduction of A Posteriori Constitutional Review of Legislation, 9 GER. L.J. 1297, 1302-03 (2008) (discussing judicial review in France).

61. See, e.g., Fiscal Compact art. 8 (empowering the ECJ to police the obligation of signatory states to incorporate the "golden rule" in their domestic legal system). See Fabbrini, supra notes 23, 25 .

62. For each of these cases, in fact, full text decisions by high courts are publicly available in a language I could read. See however Lina Papadopoulou, Can Constitutional Rules, even if 'Golden' Tame Greek Public Debt?, in The CONSTITUTIONALIZATION OF EuROPEAN BudGETARY CONSTRAINTS 223 (Maurice Adams, Federico Fabbrini \& Pierre Larouche eds., 2014), for a description of a 2012 unpublished decision in Greek by the Greek Council of State upholding the legality of the Greek statute ratifying the MoU with the troika.

63. For additional cases dealing with legal measures adopted in response to the Euro-crisis, or at least related to it, include see Verfassungsgerichtshof [VfGH] [Constitutional Court], Apr. 3, 2013, ERKENNTNISSE UND BESCHLÜSSE DES VERFASSUNGSGERICHTSHOFES [VFSLG] No. SV 2/12 (Austria) (declaring the constitutionality of the ESM Treaty) and Corte Cost., 11 ottobre 2012, n. 223/2012, Racc. uff. corte cost. (It.) (striking down a measure freezing the salaries of judges and public managers adopted in the framework of the strategy of economic readjustment undertaken by the technocratic government of Mr. Monti).

64. See Key Dates in the History of European Integration, available at http://europa.eu/abc/12lessons/key_dates/ (last visited May 10, 2013).

65. See ESM Treaty, Annex I (indicating that Germany contributes to the ESM capital with a share of 27 percent and France with a share of 20 percent) and Annex II (indicating that Germany contributes to the ESM capital with 190 billion Euros and France with 142 billion Euros). 
hoc centralized Constitutional Courts empowered to exercise judicial review of legislation, ${ }^{66}$ as is (partially) Portugal, ${ }^{67}$ whereas Ireland and Estonia endow their ordinary Supreme Courts with special powers of review. ${ }^{68}$

By taking into account judicial deliberations in jurisdictions that are varied politically, economically, and legally, this Article seeks to provide a comprehensive picture of how courts reacted to the new fiscal constitution of EMU. As such, this Article follows what Ran Hirschl has defined as the "mostdifferent-cases logic of comparison"69 whereby cases that differ under a plurality of variables are compared to emphasize the common determinant of an independent variable. In this case, the point I will seek to stress is the following: regardless of the political context of the jurisdiction in which they operate, of the economic conditions, and of the peculiarities of its system of judicial review, courts have become increasingly involved in adjudicating budgetary, financial, and economic questions. By exploring a plurality of rulings delivered by courts since the outbreak of the Euro-crisis, therefore, this Part lays the foundation for a critical discussion-to be carried out in the next Part-on the role of the judiciary and of the political process in the fiscal domain.

\section{A. Estonia}

The first challenge against the new architecture of the EMU took place before the Supreme Court of Estonia (Riigikohus). In a request submitted on February 2, 2012 (before the ratification of the ESM Treaty), the Chancellor of Justice had asked the Court to rule whether the ESM Treaty, and notably its Article 4(4), was in violation of the Estonian Constitution. The contested provision introduces, by way of derogation to the ordinary decision-making rule adopted in the ESM governing bodies (which requires unanimity), the possibility to resort to an emergency voting procedure, ${ }^{70}$ in particular, when:

[T] he Commission and the ECB both conclude that a failure to urgently adopt a decision to grant or implement financial assistance [...] would threaten to a significant extent the economic and financial sustainability of the euro area [t]he

66. See Alec Stone Sweet, Governing with Judges: Constitutional Politics in EUROPE 40-41 (2000).

67. See Antonio Cortes \& Teresa Violante, Concrete Control of Constitutionality in Portugal: A Means Toward Effective Protection of Fundamental Rights, 29 PENN ST. INT'L L. REv. 759 (2011) (explaining how under the Portuguese Constitution both ordinary courts and the Constitutional Court can review legislation, albeit in different situations and with different effects attached to their rulings).

68. See Anneli Albi, EU Enlargment and the Constitutions of Central and EASTERN EUROPE (2005) (discussing constitutional regimes of Eastern Europe, including the Baltic states); Seamus O'Tuama, Judicial Review Under the Irish Constitution: More American Than Commonwealth, 12 ELECTRONIC J. OF COMP. L. 1 (2008) (explaining the Irish system of judicial review).

69. See Ran Hirschl, The Question of Case Selection in Comparative Constitutional Law, 53 AM. J. COMP. L. 125 (2005).

70. See ESM Treaty art. 4(4). 
adoption of a decision by mutual agreement by the Board of Governors [...] requires a qualified majority of $85 \%$ of the votes cast.

In his request, the Chancellor of Justice, noticing that Estonia's contribution to the capital of the ESM (despite amounting to almost 8.5 percent of the domestic GDP) was only 0.186 percent, underlined how the Estonian vote was not decisive under the procedure and therefore raised the question whether Article 4(4) ESM Treaty was compatible with the principle of parliamentary democracy protected by the Estonian Constitution. In a very articulate decision of July 12, 2012, the majority of the nineteen-judge Supreme Court dismissed the request of the Chancellor of Justice, holding that the clause of the ESM Treaty was compatible with the Estonian Constitution. ${ }^{71}$

The Supreme Court began its opinion by summarizing the main provisions of the ESM Treaty, including its relation with EU law, ${ }^{72}$ and declared the request of the Chancellor of Justice admissible. ${ }^{73}$ The Court then outlined the "principles of the Constitution which it deem[ed] the most relevant in the adjudication of this case."74 First, the Court identified the principle of sovereignty, as protected by $\S 1(1)$ of the Estonian Constitution, but clarified that this provision had to be interpreted in "the present day context"75 and therefore rejected the idea that sovereignty ought to be regarded as absolute. Second, the Court recalled the principle of a democratic state and clarified that this meant "that the general principles of law that are recognized in the European legal space are valid in Estonia." 76 Third, the Court drew from the previous two principles, "the principle of reservation by parliament" 77 and underlined how, according to the Estonian Constitution, it was the prerogative of Parliament to pass the national budget. Moreover, the Court remarked that "the budgetary powers of the [Estonian Parliament] are one of the core competences of the [Parliament]" 78 and concluded that the "financial competence of the [Parliament] is closely related to the state's financial sovereignty and the principles of a democratic state subject to the rule of law and of reservation by the parliament." 79

In light of this framework, the Supreme Court examined whether Article 4(4) of the ESM Treaty conflicted with the Estonian constitutional principles. In this regard, the Court found that the above-mentioned clause "interfere[d] with

71. Judgment of the Supreme Court of Estonia en banc from 12 Jul. 2012, in the case 3-4-1-612 (English translation provided by the Court) [hereinafter: Est. Sup Ct., ESM judgment].

72. Id. §§ 94-107.

73. Id. $\$ \S 108-121$.

74. Id. § 126.

75. Id. $\S 128$.

76. Id. $\S 131$.

77. Id. $\$ 133$.

78. Id. $\$ 136$.

79. Id. $\$ 140$. 
the financial competence of the [Estonian Parliament]." ${ }^{80}$ Because "[d]ecisions are taken under Article 4(4) of the Treaty by a qualified majority of $85 \%$ [...] Estonia may not affect the decisions of the ESM." 81 Therefore, by ratifying the Treaty, and contributing to the ESM capital with a substantial share of domestic financial resources, the Estonian Parliament's possibility to make new future political choices on those resources was restricted because the decision could be adopted without the need of Estonia's agreement.

The composition of the [Estonian Parliament] which passes a law giving rise to the state's long-term financial obligations does not thereby restrict only its own possibilities for exercising financial competence within the same year's state budget, but also restricts the budgetary political choices of next compositions of the [Estonian Parliament]. ${ }^{82}$

According to the Court, this contrasted "with the principle of a democratic state subject to the rule of law and of the state's financial sovereignty since indirectly the people's right of discretion is restricted." 83

Nevertheless, having identified an interference by Article 4(4) of the ESM Treaty with the Constitution, the Supreme Court moved on to assess whether this interference could be regarded as justified on the basis of the proportionality test. In this regard, the Court explored the purpose of Article 4(4) and underlined how this clause introduced, by way of derogation, a voting procedure to be used only when the Commission and the ECB agree that action is needed to preserve the stability of the Euro-area. As such "Article 4(4) of the Treaty seeks to ensure the achievement of the goals of the ESM in an emergency." 84 According to the Court, "the economic and financial sustainability of the euro area is contained in the constitutional values of Estonia as of the time Estonia become a euro area Member State." ${ }^{85}$ Moreover, because "Estonia is a part of the euro area and therefore economically and financially integrated with the other euro area Member States," 86 the Court held that "a threat to the economic and financial sustainability of the euro area is also a threat to the economic and financial sustainability of Estonia." ${ }^{87}$ In the view of the Court, therefore, very pragmatic reasons weighed in favor of justifying the provisions of the ESM Treaty:

Estonia's economy and finance are closely related to the rest of the euro area and if there are economic and financial problems in the euro area, then it inevitably affects Estonia - export and import of goods and services, state budget, and thereby also social and other fields. Problems in the euro area harm also Estonia's competitiveness and reliability. The ESM as a financial assistance system may help to ensure that the euro area as a whole as well as a part of it, Estonia, would
80. $I d . \S 149$.
81. Id. $\S 150$.
82. Id. $\$ 151$.
83. Id. $\$ 153$.
84. Id. $\$ 162$.
85. Id. $\S 163$.
86. Id. $\$ 164$.
87. Id. § 165 . 
be economically and financially competitive. It is necessary to guarantee people's income, quality of life and social security. In a situation where the rest of the euro area would be in difficulties it is not probable that Estonia would be financially or economically successful, including in the field of people's income, quality of life and social security. ${ }^{8}$

At the same time, according to the Court, economic stability and success were clearly instrumental to the preservation of a supreme constitutional value, namely the protection of fundamental rights. As the Court remarked, "[e]xtensive and consistent guarantee of fundamental rights is extremely complicated, if not impossible, without a stable economic environment." ${ }^{89}$ From this point of view: "The common purpose of the euro area Member States to counter threats endangering the economy and financial stability, including by way of efficient decision-making in an emergency, coincides with the [constitutional] purpose of Estonia [...], to guarantee rights and freedoms." According to the Court, therefore:

[b]y disregarding the common purpose of the euro area Member States or the measure planned for the achievement thereof, Estonia cannot follow its objectives arising from the Constitution. Consequently, the purpose of safeguarding the efficiency of the ESM also in case the states are unable to take a unanimous decision to eliminate a threat to the economic and financial sustainability of the euro area, including of Estonia, is legitimate..$^{90}$

These strong arguments of justification for Article 4(4) of the ESM Treaty fundamentally determined the result of the Court's proportionality analysis. The Estonian Supreme Court held that the contested provision was suitable to achieve the objective of the Treaty, ${ }^{91}$ and was necessary to that end, since there were no alternative less restrictive means. ${ }^{92}$ As a matter of fact, "because Estonia's contribution to the ESM is $0.1860 \%$ [in] essence, the seriousness of the interference for Estonia would decrease only if unanimous decisions would be provided for in Article 4(4) of the Treaty."93 This option, however, would contrast with the very logic of that provision. Hence in weighing, on the one hand, the purpose of the treaty - namely "the financial stability of the euro area, including of Estonia"94-with, on the other hand the principles of the Constitution - namely "the preservation of Estonia's right to decide on its public funds" disproportionately interfere with the Estonian Constitution. ${ }^{96}$ The Court

\footnotetext{
88. Id. $\S 165$.

89. Id. $\$ 166$.

90. Id. $\$ 168$.

91. Id. $\S \S 177-180$.

92. Id. §§ 181-185.

93. Id. $\$ 184$.

94. Id. § 188.

95. Id.

96. Id. § 202.
} 
underlined how Article 4(4) was an emergency procedure. ${ }^{97}$ It stressed that financial assistance under Article 4(4) required strict conditionality. ${ }^{98}$ And it recalled how the Fiscal Compact subjected the possibility of obtaining aid under the ESM only to countries that had incorporated a "golden rule" in their Constitution..$^{99}$ Finally, the Court emphasized that:

Estonia's interests are advanced by cooperation with various international organizations and other states. This is the way to carry out the foreign and security policy which is at the final stage aimed at guaranteeing the preservation of the Estonian people, the Estonian language and the Estonian culture through the ages provided for in the preamble to the Estonian Constitution. International cooperation ensures that Estonia has in the international environment better chances of surviving and achieving its objectives. ${ }^{100}$

The Court hence concluded that the ESM Treaty did not violate the Estonian Constitution. ${ }^{101}$

The decision of the Court, nevertheless, prompted five dissenting opinions, including one supporting the substantive outcome of the case but arguing that the Court should have declared the case inadmissible. ${ }^{102}$ In a short and poignant dissent, Judge Jüri Ilvest rejected the idea that sovereignty was reshaped by globalization, criticized the lack of unanimity under Article 4(4) and concluded that it should have been only up to the Estonian people via referendum to decide whether to ratify the ESM Treaty. ${ }^{103}$ Equally, six other judges criticized the majority opinion in a joint concurrence, which notably rejected the use of proportionality analysis used to support the constitutionality of Article 4(4). ${ }^{104}$ In their dissent, the six judges emphasized how the Court should have "assessed whether the contested emergency procedure which leaves the state of Estonia out of the decision-making outweighs the sovereignty of the state of Estonia, including the financial competence of the [Estonian Parliament] and the principle of a state subject to the rule of law which are one of the most

\footnotetext{
97. Id. $\S 192$.

98. Id. $\$ 193$.

99. Id. $\$ 194$.

100. Id. $\$ 201$.

101. Although the issue was, strictly speaking, beyond the reference raised by the Chancellor of Justice, the Supreme Court devoted a final paragraph of its opinion to comment upon the relationship between the EU legal order and the Constitution of Estonia. Even if the ESM was technically neither primary nor secondary law of the EU, the Court expressed its view that the Treaty substantially "concerne[d] EU law and thereby Estonia's membership of the [EU]." Id. $\S 221$. In this light, the Court clarified that while the constitutional referendum allowing Estonia to accede the EU "allowe[d] Estonia to be part of the changing [EU] [...] [i]f it becomes evident that the new founding treaty of the $[\mathrm{EU}]$ or the amendment to a founding treaty of the [EU] gives rise to a more extensive delegation of the competence of Estonia to the [EU] and a more extensive interference with the Constitution, it is necessary to seek the approval of the holder of supreme power, i.e. the people, and presumably amend the Constitution once again.” Id. § 223 .

102. Id. (Kõve, J., dissenting).

103. Id. (Ilvest, J., dissenting).

104. Id. (Jõks, Järvesaar, Kergandberg, Kivi, Kull, and Laarmaa, Js., dissenting).
} 
substantial principles" and made clear that in their view the answer to that question ought to be negative. ${ }^{105}$ According to the dissenting opinion, there was no univocal economic-scientific analysis at the basis of the decision of the Court. ${ }^{106}$ Moreover, while the dissenters acknowledged that "participation in international cooperation is without a doubt an argument in favour of accession to the ESM Treaty," they voiced their worry that Estonia would never be able to enjoy the benefits of participation in the ESM, since, given the sheer size of its economy, a financial crisis in Estonia would not amount to a threat to the euro area as a whole. ${ }^{107}$

In a fourth dissenting opinion, Judge Tampuu criticized the decision of the Court, arguing that the proportionality test is suitable for constitutional review "where the matter of an interference with a person's fundamental rights is being adjudicated." 108 In the present case, on the contrary, the question was whether the Estonian Parliament could "waive part of its budgetary powers to the ESM." 109 According to Judge Tampuu, the answer ought to be in the negative, because the popular referendum by which Estonia had accessed the EU did not authorize the transfer "of budgetary powers to the [EU]" 110 with the result that ratification of Article 4(4) ESM Treaty could only be permitted through a constitutional amendment. Particularly critical of the majority opinion, finally, was the dissent by Judge Luik. In his view, the Estonian Constitution introduced an absolute prohibition on the alienation of sovereignty, which ought to be read in light of the history of Soviet occupation of the country.111 Moreover, according to Judge Luik, the ESM Treaty created a situation in which only wealthy countries of the euro area would benefit - running afoul of the principle of solidarity. As he remarked, "as of the adoption of the euro the consumer prices have constantly risen in Estonia. [Moreover] Estonia is without a doubt one of the poorest countries in the euro area." 112 Yet, with the ESM Treaty "Estonia undertakes to guarantee with the taxpayer's money the sustainability of the states of the euro area which are many times wealthier than Estonia, including the sustainability of the private sector (banks) of the said states." 113 Hence, Judge Luik rejected the trust of the Court's majority opinion in the "mystical efficiency of the ESM" 114 and conclusively expressed the dissent's disbelief in the capacity of the ESM to safeguard the prosperity of Estonia.

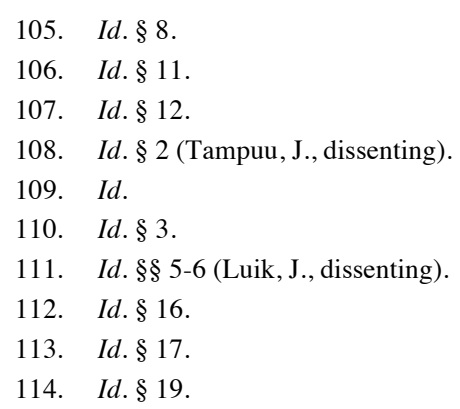


The decision of the Supreme Court of Estonia on the compatibility of Article 4(4) of the ESM Treaty with the Constitution of Estonia, if read together with the multiple dissenting opinions, reveals a favorable - but hard-foughtstand vis-à-vis the new architecture of fiscal governance in the EMU. Whereas nine dissenting judges emphasized the limitation to national sovereignty, as well as the potential economic burdens that participation in the ESM would cause to Estonia, a bare majority of ten judges emphasized the social and political advantages that would ensue from Estonian involvement in the ESM and concluded that ratification of the ESM pursued a purpose of constitutional value. ${ }^{115}$ In this regard, the majority opinion sent a message of openness toward the new mechanisms of financial stability being set up at the EU level and indicated that Estonian involvement in this new venture was a necessary condition for the future economic and financial prosperity of the country. ${ }^{116}$ Despite the sovereigntist concerns of a large part of the court, in the end, the Riigikohus, as the Supreme Court of one of the smallest member state of the Euro-zone, opted for a decision embedding the participation of Estonia in the new European fiscal architecture and simultaneously reflected the hope that a positive solution of the Euro-crisis would also favor the economic and social development of Estonia.

\section{B. France}

In July 2012, the President of the Republic asked The French Constitutional Council (Conseil Constitutionnel) to decide whether the ratification of the Fiscal Compact was compatible with the French Constitution. Pursuant to Article 54 of the 1958 French Constitution, the Constitutional Council can be asked to decide (upon referral of the President, the Prime Minister, the President of each of the two chambers of Parliament or sixty deputies or sixty senators) whether the ratification of an international treaty "contains a clause contrary to the Constitution," in which case ratification of the treaty must be preceded by a constitutional amendment. ${ }^{117}$ In its (short) decision of August 9, 2012, the Constitutional Council ruled that the Fiscal Compact did not require a constitutional change, hence validating French accession to the treaty. ${ }^{118}$

The Constitutional Council began its decision by outlining the frames of reference it would use in its review. The Council recalled that Article 3 of the 1789 Declaration of the Rights of Man and Citizen proclaimed that "the principle of all sovereignty resides essentially in the nation" and that Article 3 of

115. But see Carri Ginter \& Raul Narits, The Perspective of a Small Member States to the Democratic Deficiency of the ESM, 38 REV. OF CENTR. \& EAST EUR. L. 54 (2013).

116. See Cesare Pinelli, Le Corti europee, in PROVE DI EUROPA UNITA: LE ISTITUZIONI EUROPEE DI FRONTE ALLA CRISI 325 (Giuliano Amato \& Roberto Gualtieri eds., 2013).

117. See 1958 CONST. art. 54 (Fr.).

118. Conseil constitutionnel [CC] [Constitutional Court] decision No. 2012-653DC, Aug. 9, 2012, Rec. (Fr.) (hereinafter Fr. Const. C., Fiscal Compact judgment). 
the 1958 Constitution declares that "national sovereignty belongs to the people." 119 At the same time, it emphasized that the Preamble to the 1946 Constitution clarified that France "conforms to the rules of public international law" and "under conditions of reciprocity [...] consents to limitations of sovereignty necessary to the organization and defense of peace." ${ }^{120}$ Furthermore, it remarked that subsequent constitutional amendments to the 1958 Constitution had "enshrined the existence of a legal order [of the EU] integrated to the domestic legal order and distinct from the international legal order." 121 According to the Council, these constitutional provisions "while confirming the position of the Constitution at the summit of the domestic legal order, [...] allowed France to participate in the creation and development of a permanent European organization, endowed with legal personality and vested with decision-making powers by the transfer of competences accorded by the member States." 122 While the Council recognized that the Fiscal Compact was not technically part of EU law, it thus clarified that its review would not extend to those "clauses of the treaty which replicated obligations already subscribed by France."123

On the merits of the case, the Council chose to focus its attention on Article 3 of the Fiscal Compact, neutralizing potential incompatibilities between this clause and the French Constitution. To begin with, the Council stated that the requirement of Article 3 to strengthen the domestic budgetary constraints did not add any novel obligation for France:

France is already required to respect the rules of Article 126 [TFUE], relating to the containment of excessive States deficits, as well as Protocol $n^{\circ} 12$, annexed to the [Treaties], on the procedure concerning the excessive deficits [and] these rules include a standard of reference set at $3 \%$ for the ratio between the foreseen or effective public deficit and the gross domestic product at market prices. ${ }^{124}$

119. 1958 CONST., art. 3 (Fr.).

120. 1946 CONST., Preamb. (Fr.). Notice that the French Constitutional Court has recognized that the Preamble of the French Constitution of 1946 constitutes part of the constitutional principles on the basis of which it carries out its review. See on this Alec Stone SweEt, The BiRTh of JUdiCIAL POLITICS IN FRANCE (1992).

121. Fr. Const. C., Fiscal Compact judgment $\$ 8$ (my own translation) (“consacré l'existence d'un ordre juridique de [l'UE] intégré à l'ordre juridique interne et distinct de l'ordre juridique international.").

122. Id. §9 (my own translation) (“confirmant la place de la Constitution au sommet de l'ordre juridique interne, ces dispositions constitutionnelles permettent à la France de participer à la création et au développement d'une organisation européenne permanente, dotée de la personnalité juridique et investie de pouvoirs de décision par l'effet de transferts de compétences consentis par les États membres.").

123. Id. § 11 (my own translation) ("stipulations du traité qui reprennent des engagements antérieurement souscrits par la France").

124. Id. $\$ 15$ (my own translation) (“[L]a France est d'ores et déjà tenue de respecter les exigences résultant de l'article 126 du [TFUE], relatif à la lutte contre les déficits excessifs des États, ainsi que du protocole $\mathrm{n}^{\circ} 12$, annexé aux [TUE], sur la procédure concernant les déficits excessifs [et] ces exigences incluent une valeur de référence fixée à $3 \%$ pour le rapport entre le déficit public prévu ou effectif et le produit intérieur brut aux prix du marché.”). 
Moreover, the Council indicated that the "Six Pack" had tightened the deficit brake under EU law. ${ }^{125}$ As a result, according to the Council, the provisions of the Fiscal Compact simply re-affirmed and reinforced "the provisions putting in place the obligations of the $[\mathrm{M}]$ ember States of the [EU] to coordinate their economic policies pursuant to Articles 120 to 126 [TFUE]." ${ }^{126}$ From which it followed "that, no more than the previous budgetary obligations, the duty to respect these new rules does not challenges the essential conditions for the exercise of national sovereignty." 127

Secondly, the Council rejected a possible incompatibility between Article 3(2) of the Fiscal Compact, demanding the incorporation of the "golden rule" at the domestic level, and the French Constitution. ${ }^{128}$ As the Council clarified, after the ratification of the Fiscal Compact "France will be, pursuant to the rule pacta sunt servanda, bound by these obligations" 129 with the result that "it belongs to the various State institutions to ensure, in the framework of their respective competences, the application of the treaty." ${ }^{130}$ Nevertheless, on the specific duty to incorporate the "golden rule," the Constitutional Council underlined how Article 3(2) of the Fiscal Compact introduced:

an alternative on the basis of which the contracting States commit to give effect to the rule enshrined in Article 3(1) in their national legal order, either 'through provisions of binding force and permanent character, preferably constitutional,' or through provisions 'otherwise guaranteed to be fully respected and adhered to throughout the national budgetary processes. ${ }^{131}$

If the French government was following the first option, "choosing to incorporate the rules enshrined in Article 3(1) through provisions of binding force and permanent character, the authorization to ratify the treaty ought to be

125. See supra text accompanying note 16 .

126. Conseil constitutionnel [CC] [Constitutional Court] decision No. 2012-653DC, Aug. 9, 2012, Rec. $§ 16$ (Fr.) (my own translation) ("en les renforçant les dispositions mettant en oeuvre l'engagement des États membres de l'[UE] de coordonner leurs politiques économiques en application des articles 120 à 126 du [TFUE].").

127. Id. § 16 (my own translation) ("que, pas plus que les engagements antérieurs de discipline budgétaire, celui de respecter ces nouvelles règles ne porte atteinte aux conditions essentielles d'exercice de la souveraineté nationale.").

128. See supra text accompanying note 20 .

129. Conseil constitutionnel decision [CC] [Constitutional Court] No. 2012653DC, Aug. 9, 2012, Rec. $\$ 18$ (Fr.) (my own translation) ("la France sera, en application de la règle « pacta sunt servanda », liée par ces stipulations").

130. Id. § 18 (my own translation) ("il appartiendra aux divers organes de l'État de veiller dans le cadre de leurs compétences respectives à l'application de ce traité.").

131. Id. § 19 (my own translation) ("une alternative selon laquelle les États contractants s'engagent à ce que les règles énoncées au paragraphe 1 de l'article 3 prennent effet dans leur droit national, soit 'au moyen de dispositions contraignantes et permanentes, de préférence constitutionnelles', soit au moyen de dispositions 'dont le plein respect et la stricte observance tout au long des processus budgétaires nationaux sont garantis de quelque autre façon'.”). 
preceded by a revision of the Constitution." 132 On the other hand, if it was following the second, no constitutional revision was needed. ${ }^{133}$

As the Constitutional Council made clear, the French legal order included a legal source, the organic law (loi organique), which allowed the faithful incorporation of the "golden rule" without demanding a constitutional revision. Article 34(22) of the Constitution made possible the adoption "of an organic law [...] to set up the framework for the program laws relating to the multiannual orientation of public finances." 134 According to the Council these provisions could serve as the benchmark to assess the constitutionality of the budgetary laws adopted by Parliament. In fact, the Constitutional Council re-affirmed its duty under Article 61 of the French Constitution "to review conformity with the Constitution of the program laws on the multiannual orientation of public finances, of the budget laws and the laws for the financing of social security." 135 Moreover, it signaled its commitment to exercise this task carefully, including "by taking into account the advice of independent institutions"136 - whose creation was also demanded by the Fiscal Compact.

Having concluded that the incorporation of Article 3(2) could be accomplished simply with an organic law, the Constitutional Council also indicated that Article 8 of the Fiscal Compact, which empowers the ECJ to review the incorporation of Article 3(2) and to sanction disobedient states, raised no constitutional problem. ${ }^{137}$ According to the Council:

taking into account that Article 3(2) does not require a constitutional revision, the provisions of Article 8 do not have the effect of empowering the [ECJ] to assess, in this context, the conformity of the Constitution with the obligations of this treaty. [. . .] As a result, if France decides to give effect to the rules of Article 3(1) of the treaty with the modalities foreseen by the second branch of the alternative of the first sentence of Article 3(2), then Article 8 does not challenge the essential conditions for the exercise of national sovereignty. ${ }^{138}$

132. Id. § 21 (my own translation) ("fai[sant] le choix de faire prendre effet aux règles énoncées au paragraphe 1 de l'article 3 au moyen de dispositions contraignantes et permanentes, l'autorisation de ratifier le traité devra être précédée d'une révision de la Constitution.").

133. Id. § 28 .

134. Id. $\$ 24$ (my own translation) ("des dispositions de nature organique [...] pour fixer le cadre des lois de programmation relatives aux orientations pluriannuelles des finances publiques").

135. Id. § 27 (my own translation) ("de contrôler la conformité à la Constitution des lois de programmation relatives aux orientations pluriannuelles des finances publiques, des lois de finances et des lois de financement de la sécurité sociale").

136. Id.§ 27 (my own translation) ("en prenant en compte l'avis des institutions indépendantes").

137. See supra text accompanying note 21 .

138. Conseil constitutionnel decision [CC] [Constitutional Court] No. 2012-653DC, Aug. 9, 2012, Rec. $§ 30$ (Fr.) (my own translation) (“[c]onsidérant que, le paragraphe 2 de l'article 3 n'imposant pas qu'il soit procédé à une révision de la Constitution, les stipulations de l'article 8 n'ont pas pour effet d'habiliter la [CJUE] à apprécier, dans ce cadre, la conformité de dispositions de la Constitution aux stipulations du présent traité. [...] [P]ar suite, si la France décide de faire prendre effet aux règles énoncées au paragraphe 1 de l'article 3 du traité selon les modalitié fixées à 
With this réserve d'interprétation, the Council then briefly surveyed the other provisions of the Fiscal Compact, and found that none of them included "new binding provisions which add upon the provisions included in the [EU] Treaties." 139 As a result, it concluded that the Fiscal Compact "does not include any clause contrary to the Constitution." 140

The decision of the Constitutional Council with respect to the Fiscal Compact validated the entry into force of a central feature of the new fiscal constitution of the EMU. By interpreting the obligation of Article 3(2) as requiring simply the adoption of a loi organique, rather than a constitutional amendment, the Council largely eased the task for the French government in adopting the domestic legal instruments necessary to comply with the Fiscal Compact. ${ }^{141}$ At the same time, the Constitutional Council took the opportunity to reaffirm its position as the institution charged to review the constitutionality of budgetary laws approved by the French Parliament. Moreover, it attempted to reduce the powers of the ECJ under Article 8 of the Fiscal Compact through a restrictive reserve of interpretation (réserve d'interprétation) of that treaty. Whether this réserve d'interprétation with regard to the powers of the ECJ has any bite is doubtful. Pursuant to Article 8 of the Fiscal Compact, the ECJ will still be required to verify whether the loi organique adopted by France is compatible with the principles of Article 3(2). ${ }^{142}$ Nevertheless, by clarifying that the Fiscal Compact demanded a scrutiny of compatibility of ordinary budgetary legislation with the "golden rule" and by indicating its commitment to exercise this scrutiny attentively, the Constitutional Council seized the opportunity offered by the new European fiscal architecture and readily welcomed these institutional changes to expand its domestic powers of review.

\section{Germany}

Among the European courts, the most active one in reviewing legislation adopted in the framework of the new architecture of the Euro-zone has been the Constitutional Court of Germany (Bundesverfassungsgericht). ${ }^{143}$ To begin with, on September 7, 2011, the Constitutional Court delivered a judgment on the compatibility with the German Basic Law of the first rescue package adopted to aid Greece. ${ }^{144}$ The case concerned the legislation adopted by the German

la seconde branche de l'alternative de la première phrase du paragraphe 2 de l'article 3 , l'article 8 ne porte pas atteinte aux conditions essentielles d'exercice de la souveraineté nationale.").

139. Id. $\S 35$ (my own translation) ("contient de clause nouvelle contraignante qui s'ajouterait aux clauses contenues dans les traités relatifs à [l'UE].").

140. Id. $\S 36$ (my own translation) ("ne comporte pas de clause contraire à la Constitution.").

141. See David Jolly \& Jack Ewing, France's Highest Court Clears E.U. Fiscal Treaty, THE INT'L HERALD TRIB., Aug. 11-12, 2012, at 9.

142. See supra notes $23,25$.

143. See also infra Table 1 .

144. BVerfG, Case No. 2 BvR 987/10, judgment of 7 Sept. 2011 (upholding the EFSF and the Euro-rescue package) [hereinafter BVerfG, EFSF judgment]. 
Parliament to implement the EFSF and to allow the payment of an emergency loan for the financial assistance of Greece. ${ }^{145}$ Through individual complaints (Verfassungsbeschwerde), a number of citizens had challenged the constitutionality of these domestic measures as a violation of the right of the German Parliament to make decisions about the budget, and therefore as an interference with the right to democracy protected (as inviolable) by the Basic Law. The Second Senate of the Constitutional Court declared the case admissible but rejected the constitutional complaints, holding that the two pieces of legislation under review did not violate the Parliament's budgetary autonomy. ${ }^{146}$ The Court, however, affirmed that any large amount of financial aid had to be approved by Parliament as the locus of democratic legitimacy, and thus required an interpretation of the legislation as imposing prior involvement of the Parliament on every decision by the Federal Government to accord financial guarantees under the EFSF. ${ }^{147}$

Moreover, the Constitutional Court was also at the center of public attention in 2012 when it was asked to review the constitutionality of the ESM Treaty and the Fiscal Compact. ${ }^{148}$ This case, which had originated from an interinstitutional proceeding (Organstreit) brought by the parliamentary group Die Linke and by five individual constitutional complaints, sought to obtain a temporary injunction preventing the German Federal President from signing the Fiscal Compact, the ratification of the amendment to Article 136(3) TFEU, and the ESM Treaty. While from the procedural point of view the case only required a decision on preliminary measures (pending decision on the merits), the Constitutional Court carried out a summary review of the complaints, de facto undertaking a substantive control of the legislation pending before it. ${ }^{149}$ In its

145. For a comment to the decision see Sebastian Recker, Casenote-Euro Rescue Package Case: The German Federal Constitutional Court Protects the Principle of Parliamentary Budget, 12 GER. L.J. 2071 (2011).

146. BVerfG, EFSF judgment, $\S \S 94,119$.

147. The decision opened a stream of litigation before the Constitutional Court on the precise role of the Parliament vis-à-vis the Government on issues related to the responses to the Euro-crisis. See BVerfG, Case No. 2 BvE 8/11, Feb. 28, 2012 (holding that legislation allowing a special 9member committee of the Bundestag to authorize, in cases of emergency, the government to act in the management of the EFSF violated the right of the Parliament, as a whole, to be involved in decisions relating to the EFSF); BVerfG, Case No. $2 \mathrm{BvE} \mathrm{4/11,} \mathrm{June} \mathrm{19,} 2012$ (holding that the Government had violated the right of the Parliament to be fully and comprehensively informed about the negotiation undertaken at the EU level for the adoption of the Euro-plus Pact and of the ESM Treaty). See Susanne Schmidt, A Sense of Déjà Vu? The FCC's Preliminary European Stability Mechanism Verdict, in 14 GER. L. J. 1, 10-11 (2013).

148. As acknowledged in an interview by Andreas Vosskuhle, the President of the German Constitutional Court: See Frédéric Lamaître, L'Europe à l'épreuve des tribunaux, LE MONDE, 2 Oct. 2012 (emphasizing how the judgment had been awaited all over the world and how the Court had a special responsibility).

149. The German Constitutional Court is expected to deliver its final judgment on the case in 2014. Because the ruling was, albeit summary, very detailed, it is expected that the final judgment will largely confirm the interim decision. However, a thorny issue which the Bundesverfassungsgericht has decided to address incidenter tantum in its final case, concerns the 
judgment of September 12, 2012, the Constitutional Court rejected the request for temporary injunction, holding that the Fiscal Compact, the amendment to the Article 136(3) TFEU, and the ESM Treaty were compatible with the German Basic Law, although in the case of the latter, the Court indicated two conditions that Germany had to clarify with a declaration under international law. ${ }^{150}$

The Court, after describing in detail the facts leading to the adoption of the ESM Treaty and of the Fiscal Compact, ${ }^{151}$ their content, ${ }^{152}$ as well as the legislation adopted by the German Parliament to implement them at the domestic level, ${ }^{153}$ outlined the constitutional principles that it would consider in its review. Here, by building on its previous decisions on EU integration, ${ }^{154}$ the Court stated that the right to elect the German lower house of Parliament (Bundestag) enshrined in Article 38(1) of the German Basic Law is "a right equivalent to a fundamental right, guarantees the citizens' self-determination and guarantees free and equal participation in the state authority exercised in Germany." 155 As such, in the Court's view, Article 38(1) renders justiciable the principle of democracy of Article 20 of the Basic Law, which is "protected by Article 79(3) of the Basic Law as the identity of the constitution even against interference by the constitution-amending legislature." 156 Furthermore, the Court clarified that "[t]here is a violation of Article 38(1) of the Basic Law in particular if the German Bundestag relinquishes its parliamentary budget responsibility with the effect that it or a future Bundestag can no longer exercise the right to decide on the budget on its own responsibility." 157 According to the Constitutional Court, in fact, "[t]he decision on public revenue and public expenditure is a fundamental part of the ability of a constitutional state to democratically shape itself." 158

As a corollary to this, the Court made five additional statements which developed notions already advanced in its decision of September 7, 2011. First, it held that "[a]s representatives of the people, the elected Members of the

power of the ECB to undertake non-conventional monetary policies. See infra note 183.

150. BVerfG, Case No. 2 BvR 1390/12 et al., judgment of Sept. 12, 2012 [hereinafter BVerfG, ESM judgment] (English translation partially provided by the court. Please note that, unless otherwise stated, the citations below are all drawn from the English translation of the judgment. Please also note that, because not the entire decision is translated in English, the numbering of the paragraphs in the German and the English versions of the judgment do not correspond. When the text cites the decision in German, the footnote will cite explicitly to the German version with the corresponding number referring to the German version).

151. Id. $\$ \S 2-10$.

152. Id. $\S \S 11-107$.

153. Id. $\$ \S 108-145$.

154. See generally Erich Vranes, German Constitutional Foundations of, and Limitations to, EU Integration: A Systematic Analysis, 14 GER. L. J. 74 (2013).

155. BVerfG, ESM judgment, § 192.

156. Id. $\$ 192$.

157. Id. $\S 194$.

158. Id. $§ 194$. 
German Bundestag must retain control of fundamental budgetary decisions even in a system of intergovernmental governing." "Bundestag may not deliver itself up to any mechanisms with financial effect which [...] may result in incalculable burdens with budget significance without prior mandatory consent." 160 Third, it emphasized the need for the "budget legislature [to] make[] its decisions on revenue and expenditure free of otherdirectedness on the part of the bodies and of other Member States of the European Union [so as to] remain[] permanently 'the master of its decisions."" 161 Fourth, it repeated that the "Bundestag must individually approve every large-scale federal aid measure on the international or European Union level made in solidarity resulting in expenditure."162 And finally, it underlined that the Bundestag ought to be able to have access to the information needed to exercise its budgetary competence. ${ }^{163}$ Nevertheless, the Constitutional Court acknowledged that the Bundestag enjoyed "latitude" in deciding what budgetary commitments to undertake vis-à-vis the EU partners, ${ }^{164}$ and - after emphasizing how the EU Treaties provisions on EMU had established a "stability community,"165 aimed at protecting the Bundestag's overall budget responsibility - it stated that "[i]t is for the legislature to decide how possible weaknesses of the monetary union are to be counteracted by amending [EU] law."166

In light of this framework of reference, the Constitutional Court held that the legislation implementing the ESM Treaty "essentially [took] account of the requirements of Article 38(1), Article 20(1) and (2) in conjunction with Article 79(3) of the Basic Law." 167 Nevertheless, since certain interpretations of the provisions of the ESM Treaty might violate the Bundestag's overall budgetary responsibility, the Court required that this "be effectively precluded by declarations under international law made upon ratification of the Treaty." 168 One set of provisions of the ESM to be clarified was that on revised increased capital calls (Article 9(2) and (3), sentence one in conjunction with Article 25(2) of the ESM Treaty). ${ }^{169}$ Although Article 8 of the ESM Treaty "bindingly limit[ed]" Germany's budgetary commitments to 190 billion euros, ${ }^{170}$ the Court indicated that the Basic Law prohibited any increase beyond that "without the

\footnotetext{
159. BVerfG, ESM judgment, § 195.

160. Id. § 196.

161. Id. § 197.

162. Id. $\$ 198$.

163. Id. $\$ 199$.

164. Id. $\$ 201$.

165. Id. § 203.

166. Id. $\$ 206$.

167. Id. § 208.

168. Id. § 209.

169. See supra text accompanying note 39 .

170. BVerfG, ESM judgment, § 212.
} 
ratification of the Bundestag." ${ }^{171}$ As such, the Court demanded that the German government, at the act of ratification of the ESM Treaty and "to remove [...] doubts," 172 declare that the "provisions of this Treaty [...], may only be interpreted or applied in such a way that no higher payment obligations are established for [. . .] Germany." 173

Another set of provisions of the ESM to be clarified was the inviolability of documents (Articles 32(5) and 35(1)) and the professional secrecy of the legal representatives of the ESM (Article 34). ${ }^{174}$ While these provisions admitted "an interpretation which makes sufficient parliamentary monitoring of the [ESM] by the German Bundestag possible," 175 the Court held that, since the Treaty made no "exception in favour of the national parliaments," 176 a specific declaration ought to secure this possibility. According to the Court, the secrecy of the ESM only intended to "prevent a flow of information to unauthorized third party," 177 but could not be opposed vis-à-vis "the parliaments of the Member States, including the Bundestag." 178 The duty to keep the national parliaments, as holders of budgetary authority, fully informed about the ESM, otherwise, was all the more important for the following reason: "due to the form chosen for the treaty - that of an international treaty complementing the integration programme of the European Union [...] - no monitoring by the European Parliament is possible." ${ }^{\prime 19}$ For this reason, the Court required the German government, at the act of the ratification of the ESM Treaty, to make a declaration interpreting the Treaty in a way "which guarantees that with regard to their decisions, [both chambers of the German Parliament] will receive the information which they need to be able to develop an informed opinion." 180

The Constitutional Court, instead, held that Article 4(8), which suspends voting rights for states that failed to meet their obligations to pay the ESM, was not incompatible with the German Basic Law. ${ }^{181}$ Moreover, it held that the Bundestag was free to decide to contribute up to 190 billion euros to the ESM capital. According to the Court:

The Bundestag and the Federal Government stated in detail that the risks involved with making available the German shares in the [ESM] were manageable, while without the granting of financial facilities by the [ESM] the entire economic and social system was under the threat of unforeseeable, serious consequences. Even

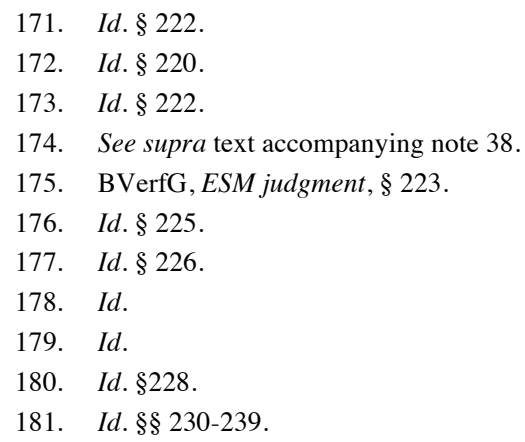


though these assumptions are the subjects of great controversy among economic experts, they are at any rate not evidently erroneous. Therefore the Federal Constitutional Court may not replace the legislature's assessment by its own. ${ }^{182}$

Finally, the Court summarily rejected the complaint raised against other provisions of the ESM Treaty for alleged violation of the prohibition of monetary financing, but already signaled its attention towards the issue of a circumvention of Article 123 of the TFEU by the ECB. ${ }^{183}$ Here the Court held inter alia that " $[\mathrm{t}]$ he ban on monetary financing as an important element for safeguarding the constitutional requirements of the precept of democracy under [EU] law [...] [wa]s not affected by the Treaty establishing the [ESM]."184 And, citing the ECJ in support ${ }^{185}$ of the statement that "[a]s an internal agreement between [EU] Member States, the Treaty establishing the [ESM] must at any rate be interpreted in conformity with [EU] law," 186 it stressed that the ESM could not bypass the prohibition of monetary financing by the ECB enshrined in the EU Treaties. ${ }^{187}$

Unsurprisingly, then, the German Constitutional Court in its decision of September 12, 2012, also gave its approval to the ratification of the Fiscal Compact. As I argued elsewhere, in fact, the main provisions of the Fiscal Compact were modeled on the balanced budget rules introduced in the German Basic Law with the Federalism Reform of 2009. ${ }^{188}$ The Constitutional Court, therefore, acknowledged that Article 3(2) Fiscal Compact was almost identical with the existing requirements of the German Basic Law, ${ }^{189}$ and simultaneously underlined how the other provisions of the Fiscal Compact replicated requirements already existing under EU law. ${ }^{190}$ Moreover, cross-referencing the

182. Id. $\S 240$.

183. See supra note 27. The question whether action by the ECB is in violation of Article 123 of the TFEU is now at the core of another major case pending before the German Constitutional Court. See 2 BvR 1390/12, 2 BvR 1421/12, 2 BvR 1438/12, 2 BvR 1439/12, 2 BvR 1440/12, 2 BvR $1824 / 12$ and 2 BvE 6/12 [Cases 2 BvR 1390/12 et al.]. The case concerns the decision by the ECB to activate a program called Outright Monetary Transaction (OMT), which allows the purchase of government bonds on the secondary market to secure the effective transmission of the ECB monetary policy. See ECB, Press Release, Technical Features of Outright Monetary Transaction, 6 Sept. 2012, available at: http://www.ecb.europa.eu/press/pr/date/2012/html/pr120906_1.en.

html. The legality of the OMT has been discussed in hearings before the German Constitutional Court in June 2013. See Michael Steen, 'ECB Heavyweights Slug it out in German Court', THE FIN. TiMES, June 10, 2013, at 6 .

184. Id. $\S 245$.

185. Case C-235/87 Matteucci [1988] E.C.R. I-5899.

186. BVerfG, ESM judgment, $\$ 245$.

187. On the challenges associated with the forthcoming decision of the German Constitutional Court in the so-called OMT case, see Alexander Koch, A Guide for the German Constitutional Court Hearing on the OMT, Unicredit Research Paper, June 5, 2013.

188. See supra notes 23, 10 (explaining that the German constitutional reform of 2009 functioned as the model for the text of the Fiscal Compact).

189. BVerfG, ESM judgment, $\S 301$ [German version of the judgment].

190. Id. $\$ 303$ [German version of the judgment]. 
decision of the French Constitutional Council on the matter, the German Constitutional Court excluded that the Fiscal Compact empowered EU institutions to take action that had a direct effect on national budgetary legislation. ${ }^{191}$

In sum, in all its decisions reviewing the legal measures adopted at the EU level, and implemented in Germany, to respond to the Euro-crisis, the German Constitutional Court eventually upheld the contested provisions as in conformity with the Basic Law. ${ }^{192}$ Nevertheless, while the pressures of the events probably forced the Bundesverfassungsgericht to reach these conclusions, the Court, as it has become customary in its decisions related to EU integration, also did not fail to express its skepticism toward the most recent developments occurring in the EU constitutional framework. It repeatedly acted to strengthen the role of the Bundestag, as the authority vested with the constitutionally reserved function to make fundamental decisions on budgetary issues and as the only institution-in the Court's view - which enjoys legitimacy to decide about financial matters. ${ }^{193}$ And, in the case of the ESM Treaty, it explicitly required the German government to accompany its ratification with two declarations under international law clarifying that nothing in the Treaty could be interpreted as increasing the share of Germany to the ESM capital without the approval of the Bundestag or as depriving the Bundestag of the right to obtain all information about the internal functioning of the ESM. ${ }^{194}$ The Court certainly recognized that the political branches have the lead in devising strategies to address the crisis, ${ }^{195}$ but it confirmed that ultimately it will be up to the Court to sanction whatever legal measure is adopted-as is currently the case with the OMT policy of the ECB. ${ }^{196}$ As further crucial decisions on the new EMU by the highest German court are expected in the near future, the forecasts do not look promising. ${ }^{197}$

191. Id. $\S 311$ [German version of the judgment].

192. See JHR/WTE, Editorial, Watching Karlsruhe/Karlsruhe Watchers, 8 EUR. CON. L. REV. 367 (2012).

193. See Mattias Wendel, Judicial Restraint and the Return to Openness: the Decision of the German Federal Constitutional Court on the ESM and the Fiscal Treaty of 12 September 2012, 14 GER. L. J. 21, 32 (2013).

194. See Karsten Schneider, Yes, But. . One More Thing: Karlsruhe's Ruling on the European Stability Mechanism, in 14 GER. L. J. 54 (2013), available at http://www.voxeu.org/article/wisdomkarlsruhe-omt-court-case-should-be-dismissed.

195. See Wendel, supra notes $188,42$.

196. See Francesco Giavazzi et al., The Wisdom of Karlsruhe: the OMT Court case should be dismissed, VOYEUX.ORG, June 12, 2013.

197. See also Bruce Ackerman \& Miguel Maduro, Broken Bond, ForEIGN POLICY, Sept. 17, 2012 (arguing that "Germany's Constitutional Court may have just saved the euro, but it may also have set the stage for the end of Europe as we know it."). 


\section{Ireland}

The legality of the ESM Treaty was also at the heart of a constitutional challenge in Ireland. On April 13, 2012, Mr. Pringle, a member of the Irish Parliament, commenced an action before the High Court of Ireland against the ratification of the ESM Treaty, arguing that this was in violation of the Irish Constitution as well as EU law. In particular, Mr. Pringle complained that Ireland's participation in the ESM involved a delegation of sovereignty and a transfer of powers in violation of the Irish Constitution, that the obligations stemming from the ESM Treaty were in contravention of EU law and, moreover, that the Decision 2011/199/EU of the European Council-modifying through a simplified revision procedure Article 136 TFEU to allow the Euro-zone member states to establish a stability mechanism - was adopted unlawfully and was inconsistent with provisions of the Treaties and with the general principles of EU law. For these reasons, Mr. Pringle sought an injunction restraining the Irish government from ratifying the ESM Treaty. The High Court heard the case and, in a judgment of July 17, 2012, dismissed the appellant's claim under all headings. ${ }^{198}$

After analyzing in detail the provisions of the ESM Treaty and the constitutionally entrenched principles of the TFEU, the High Court declared itself "satisfied that the plaintiff's claim that the ESM Treaty is incompatible with [EU] law has not been established." 199 At the same time, the High Court rejected the petitioner's claim with regard to a breach of the Irish Constitution. First, the Court excluded that the ESM affected a limitation of Irish sovereignty, arguing that the "participation of the State in the ESM Treaty [made] its consent [...] necessary in all cases (with the exception of the application of Article 4(4)) where significant decisions must be made." ${ }^{200}$ Second, the Court denied that the ratification of the ESM determined a transfer of budgetary powers from the legislature to the executive emphasizing how the "limit on payments by the State to the ESM [...] cannot be exceeded without the approval of [the Irish Parliament]."201 Third, the Court held that, because the ESM Treaty was not incompatible with EU law, "an amendment of the Constitution approved of by the people in a referendum [wa]s not necessary before [Ireland could] ratif[y]" the Treaty. ${ }^{202}$ The Court then considered the legality of the European Council decision modifying Article 136 TFEU and found it "“completely valid' in accordance with [EU] law." 203 As such, citing Foto-Frost, ${ }^{204}$ the Court discarded the plaintiff's request for a preliminary reference.

\footnotetext{
198. Pringle v. The Gov’t of Ireland, [2012] IEHC 296 [hereinafter: Ir. H. Ct., Pringle].

199. Id. $\$ 90$.

200. $\quad I d . \S 128$.

201. Id. 133 .

202. Id. $\$ 140$.

203. Id. $\$ 163$.

204. Case 314/85, Foto-Frost, [1987] E.C.R.I-4199.
} 
Mr. Pringle appealed the decision to the Irish Supreme Court, which on July 31, 2012, delivered its judgment. ${ }^{205}$ In its ruling, the Supreme Court summarily upheld the decision of the High Court, rejecting the sovereignty claim of Mr. Pringle and his request for an injunction preventing the ratification of the ESM Treaty. ${ }^{206}$ At the same time, the Supreme Court decided to stay proceedings and submit a reference to the ECJ on the question of the compatibility of the ESM Treaty and of European Council Decision 2011/199/EU with the EU Treaties. ${ }^{207}$ In particular, the Supreme Court asked the ECJ whether European Council Decision 2011/199/EU was valid having regard to the use of simplified revision procedure and the content of the amendment. Moreover, it asked the ECJ whether, in light of the provisions of the EU Treaties regulating the EMU and the general principles of EU law, a member state like Ireland was entitled to enter into and ratify an international agreement such as the ESM Treaty. Finally, it asked the ECJ to clarify whether the ratification of the ESM Treaty was subject to the entry into force of the amendment of Article 136 TFEU introduced by Decision 2011/199/EU. Taking into account that "the ESM Treaty Members, including Ireland, and the Member States of the European Union all have pressing interest in Ireland's timely ratification of the ESM Treaty and that the stability of the euro area would be seriously damaged by delayed ratification" and noticing that the ESM Treaty is "of the utmost importance for other Members of the ESM, and, in particular, the Members who are in need of financial assistance," the Supreme Court asked the ECJ to submit its reference to the accelerated procedure, in order to solve as soon as possible a "matter [ . . .] of exceptional urgency."208

The position of the Irish judiciary, as emerging both from the decision of the High Court and of the Supreme Court, reveals the interconnections between domestic and EU questions relating to the legality of the ESM Treaty ${ }^{209}$ While the High Court held that no need arose for a preliminary reference to the ECJ, because the ESM was fully valid, it systematically analysed the provisions of the ESM Treaty and of the TEU and the TFEU also in light of the case law of the ECJ, and rejected any form of incompatibility with the Irish Constitution or with EU law. The Supreme Court, instead, reflecting more concerns about the legality of the ESM, decided to make direct recourse to the preliminary reference procedure, thus exploiting the institutional machinery specifically designed under the TFEU to ensure the dialogue between state courts and the ECJ, to demand the opinion of the ECJ in the resolution of a legal matter affecting the

205. Pringle v. The Gov't of Ireland, [2012] IESC 47 [hereinafter: Ir. S. Ct., Pringle].

206. Id. (ruling).

207. Id. (preliminary reference).

208. See also CJEU Pringle, supra note 2 (order of reference).

209. See Jonathan Tomkin, Contradiction, Circumvention and Conceptual Gymnastics: The Impact of the Adoption of the ESM Treaty on the State of European Democracy, 14 GER. L. J. 170 (2013). 
entire Euro-zone..$^{210}$ The Supreme Court's decision, therefore, settled the constitutional question surrounding the ESM Treaty and simultaneously offered to the ECJ the opportunity to be involved in the debate about the legality of the ESM. We now turn to the decision of the ECJ.

\section{E. The European Court of Justice}

The ECJ accepted to hear the preliminary reference of the Irish Supreme Court through the accelerated procedure and delivered its decision on November $27,2012 .{ }^{211}$ Given the relevance of the case, reflected in the intervention before the ECJ of twelve governments and all three EU institutions, the ECJ chose to decide as a full court, composed of all twenty-seven judges. The ECJ began by outlining the legal context. It then addressed separately the three preliminary questions raised by the Irish Court. First, whether Decision 2011/199/EU was valid with regard to the use of the simplified revision procedure pursuant to Article 48(6) of the TEU and, in particular, whether the proposed amendment to Article 136 to the TFEU involved an increase in the competences conferred on the EU in the Treaties or a violation of the Treaties and general principles of EU law. Second, whether a member state of the EU was authorized to ratify the ESM Treaty, having regard to Treaty provisions relating to the EU exclusive competence, those relating to economic policy, those concerning the role of the institutions, as well as the principles of sincere cooperation and of effective judicial protection. And, third, whether the ratification of the ESM Treaty could be undertaken before the entry into force of Decision 2011/199/EU. The ECJ responded in the affirmative to all three questions.

To respond to the first question, the ECJ started with a clarification of its jurisdiction. Rejecting the position of several states' governments, the ECJ held it was competent to examine the validity of European Council Decision 2011/199/EU. On the one hand, the ECJ recalled how the decision was an act of an institution, and thus fell within its purview under Article 267 of the TFEU. On the other, the ECJ noted that, because Article 48(6) of the TEU set a number of conditions on the use of the simplified revision procedure to amend the Treaties, "it $\mathrm{f}[\mathrm{e}] 11[]$ to the Court, as the institution which, under the first subparagraph of Article 19(1) TEU, is to ensure that the law is observed in the interpretation and application of the Treaties, to examine the validity of a decision of the European Council based on Article 48(6) TEU."212 In particular, the ECJ indicated that its task was to verify:

[F]irst, that the procedural rules laid down in Article 48(6) TEU were followed

210. On the use of preliminary references by Irish courts see ElAINE FAHEY, PRACTICE AND Procedure in PRELIMINARY REFERENCES TO EuRope: 30 YeARS OF ARTICle 236 EC CASElaW FROM THE IRISH COURTS (2007), which emphasizes the role of the preliminary reference procedure as the institutional mechanism to connect national courts with the ECJ.

211. CJEU Pringle, supra note 2.

212. Id. $\$ 35$. 
and, secondly, that the amendments decided upon concern only Part Three of the FEU Treaty, which implies that they do not entail any amendment of provisions of another part of the Treaties on which the European Union is founded, and that they do not increase the competences of the Union. ${ }^{213}$

Having firmly established its jurisdiction to review the legality of Treaty amendments, the ECJ moved to consider the substance of the challenge on Decision 2011/199/EU. ${ }^{214}$ Here, the ECJ separately examined whether the amendment of the TFEU envisaged by Decision 2011/199 solely concerned provisions of Part Three of the TFEU and whether it increased the competences conferred on the EU in the Treaties. On the former, the ECJ remarked that Decision 2011/199/EU formally introduced a change to Article 136 of the TFEU, which is a provision of Part III of the TFEU. ${ }^{215}$ However, the ECJ also examined whether the Decision substantially affected other parts of the TFEU, notably the monetary policy indicated by Article 3(1)(c) of the TFEU as an area of exclusive competence of the EU. According to the ECJ the objectives pursued (and the instruments foreseen) by the stability mechanism envisaged by Decision 2011/199/EU served "to complement the new regulatory framework for strengthened economic governance of the Union" 216 and therefore fell "within the area of economic policy." 217 Otherwise, the ECJ underlined how "the provisions of the EU and FEU Treaties d[id] not confer any specific power on the Union to establish a stability mechanism of the kind envisaged by Decision 2011/199."218 As a result, the "Member States whose currency is the euro are entitled to conclude an agreement between themselves for the establishment of a stability mechanism of the kind envisaged by Article 1 of Decision 2011/199." 219 In addition, on the question of whether the decision increased the competences conferred on the Union in the Treaties, the ECJ stated that the new Article 136(3) of the TFEU simply "confirm[ed] that Member States have the power to establish a stability mechanism and is further intended to ensure, by providing that the granting of any financial assistance under that mechanism will be made subject to strict conditionality, that the mechanism will operate in a way that will comply with [EU] law." 220 Hence, the

213. Id. §36.

214. The ECJ also preliminarily discarded the procedural argument raised by the Irish government that the case was inadmissible, because the applicant should have directly challenged Decision 2011/199/EU with an action under Article 163 of the TFEU. As the ECJ argued, in fact, "it [wa]s not evident that the applicant in the main proceedings had beyond doubt standing to bring an action for the annulment of Decision 2011/199 under Article 263 TFEU": Id. § 42.

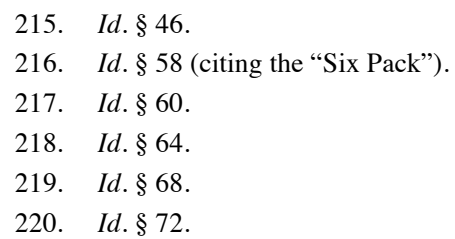


ECJ concluded that Decision 2011/199/EU was lawfully adopted in compliance with the simplified revision procedure..$^{221}$

To respond to the second question raised by the Irish Supreme Court, the ECJ examined one by one a multiplicity of provisions of the EU Treaties indicated by the referring court, in order to assess whether any of them precluded an EU member state from ratifying the ESM Treaty. According to the ECJ, none of these provisions produced such an effect. First, the ECJ restated that the ESM was not incompatible with Articles 3(1)(c) and 127 of the TFEU regulating the EU monetary policy, including its primary objective of price stability, since "[e]ven if the activities of the ESM might influence the rate of inflation, such an influence would constitute only the indirect consequence of the economic policy measures adopted." 222 Second, the ECJ discarded the argument that the ESM conflicted with Article 3(2) of the TFEU, which gives to the EU exclusive jurisdiction in concluding international agreements in the fields in which it has exclusive internal powers, holding that-since no "provision of the [...] Treaties confer[red] a specific power on the Union to establish a permanent stability mechanism such as the ESM [...] the Member States [we]re entitled [. . . to act in this area" 223 while, at the same time, nothing "prevented the Union from exercising its own competences in the defence of the common interest." 224 Third, the ECJ held that the ESM was not incompatible with Treaty provisions on economic policy-Articles 2(3), 119, 120, 121 and 126 of the TFEU. The ECJ reiterated that "the Member States have the power to conclude between themselves an agreement for the establishment of a stability mechanism such as the ESM Treaty provided that the commitments undertaken [...] are consistent with [EU] law" 225 and noted that, because "the ESM is not concerned with the coordination of the economic policies of the Member States, but rather constitutes a financing mechanism" 226 no problem of compatibility arose.

Most importantly, however, the ECJ rejected the argument that the ESM violated Articles 122, 123 and 125 of the TFEU, which concern the well-known rules of solidarity assistance, prohibition of monetary financing, and prohibition of bail-out. ${ }^{227}$ On Article 122, the ECJ held that since that clause did:

not constitute an appropriate legal basis for any financial assistance from the Union to Member States who are experiencing, or are threatened by, severe financing problems, the establishment of a stability mechanism such as the ESM does not encroach on the powers which that provision confers on the Council. ${ }^{228}$

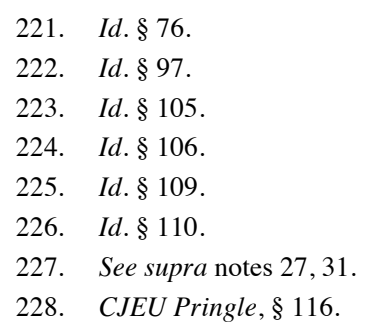


On Article 123, the ECJ underlined how this clause was textually phrased to prohibit the ECB and other central banks from directly purchasing governments' bonds, so that "[t]he grant of financial assistance by one Member State or by a group of Member States to another Member State [was] not covered by that prohibition." 229 On Article 125, then, the ECJ stated that this clause was "not intended to prohibit either the Union or the Member States from granting any form of financial assistance whatever to another Member State."230 This reading was supported by both a systematic interpretation of the Treaty-given that among others Article 122 of the TFEU did provide for forms of assistance-and an analysis of the original intent of the Treaty drafters. According to the ECJ, from the preparatory work of the Maastricht Treaty it emerged that "[t]he prohibition laid down in Article 125 TFEU [was designed to] ensure[] that the Member States remain subject to the logic of the market when they enter into debt." ${ }^{231}$ Hence, Article 125 of the TFEU only prohibited those grants of financial assistance "as a result of which the incentive of the recipient Member State to conduct a sound budgetary policy [would] diminish[]." 232 This was not, however, the case of the ESM. In fact, on the basis of the ESM Treaty:

stability support may be granted to ESM Members which are experiencing or are threatened by severe financing problems only when such support is indispensable to safeguard the financial stability of the euro area as a whole and of its Member States and the grant of that support is subject to strict conditionality appropriate to the financial assistance instrument chosen. ${ }^{233}$

The ESM did not act as a guarantor of the debts of the recipient member state, ${ }^{234}$ and no other state would be liable for the commitments of an ESM state facing default. ${ }^{235}$ In light of this, the ECJ concluded that Article 125 of the TFEU was no obstacle to the adoption of the ESM Treaty.

The ECJ also set aside the concern that the ESM Treaty was incompatible with the principle of sincere cooperation (Article 4(3) of the TEU). ${ }^{236}$ It ruled that the attribution by the ESM Treaty of specific tasks to some EU institutions (the ECB, the Commission and the ECJ) did not violate Article 13 of the TEU, stressing that its case law, or specific provisions of the Treaty such as Article 273 of the TFEU, entitled the member states, "in areas which do not fall under the exclusive competence of the Union, to entrust tasks to the institutions, outside the framework of the Union, [. . .] provided that those tasks do not alter the essential character of the powers conferred on those institutions by the EU

229. Id. $\$ 125$.

230. Id. § 130.

231. Id. § 135.

232. Id. $\$ 136$.

233. Id. § 142 .

234. Id. $\$ 138$.

235. Id. § 146.

236. Id. § 152 . 
and FEU Treaties." ${ }^{237}$ Last but not least, the ECJ denied that the ESM Treaty ran afoul of the general principle of judicial protection enshrined in the EU Charter of Fundamental Rights. In fact, in the view of the ECJ, the Charter is addressed "to the Member States only when they are implementing Union law." 238 Yet, in establishing the ESM, the member states were not implementing EU law, and, as a result, they were not subject to the scope of application of the Charter ${ }^{239}$ On the third question raised by the Irish Supreme Court, then, the ECJ briefly answered that Ireland was entitled to conclude and ratify the ESM Treaty before the entry into force of the amendment of Article 136 of the TFEU. Because Decision 2011/199/EU simply confirmed the existence of a power possessed by the member states and did "not confer any new power on the $[\mathrm{m}]$ " 240 according to the ECJ, the right of a Member State to sign and ratify that Treaty was not conditional on the entry into force of Decision 2011/199/EU. ${ }^{241}$

In conclusion, the ruling of the ECJ attentively addressed all the questions raised by the Irish Supreme Court in its preliminary reference and set aside any doubt about the compatibility of the ESM Treaty with EU law, ${ }^{242}$ thus giving its (ex post) blessing to its entry into force. ${ }^{243}$ The reasoning of the ECJ-astutely neutralizing questions of incompatibility between the ESM and the provisions of the TEU and TFEU-suggests a favorable stand vis-à-vis the ESM-an instrument which, although developed outside the framework of the EU law, directly contributes to the financial stability of the euro-zone. ${ }^{244}$ At the same time, while the ECJ concluded that the amendment of Article 136 of the TFEU, as brought about by Decision 199/2011/EU, was purely declaratory, confirming a power that the member states already had, it took the opportunity presented by the case to emphasize its role in reviewing the constitutionality of treaty amendments pursuant to the simplified revision procedure. ${ }^{245}$ In the end, nevertheless, following previous practice by the ECJ in the field, ${ }^{246}$ the ruling ensured a wide margin for member states to maneuver in responding to the

237. Id. § 158.

238. Id. $\$ 179$.

239. Id. $\$ 180$.

240. Id. $\$ 184$.

241. Id. $\$ 185$.

242. Pieter-Augustijn van Malleghem, Pringle: A Paradigm Shift in the European Union's Monetary Constitution, 14 GER. L. J. 141 (2013).

243. The ESM Treaty had entered into force on September 27, 2012, after the German deposit of the instrument of ratification. See supra text accompanying note 36.

244. See Paul Craig, Pringle: Legal Reasoning, Text, Purpose and Teleology, 20 MAASTR. J. EUR. \& COMP. L. 3 (2013).

245. See also Verstert Borger, The ESM and the European Court's Predicament in Pringle, 14 GER. L. J. 113 (2013).

246. See, e.g., Case C-27/04, Comm'n v. Council of the EU [2004] E.C.R. I-6649 (recognizing wide discretion to the Council whether to impose sanctions under the SGP or held in abeyance the excessive deficit procedure against two member states recommended by the Commission). 
turmoil of the Euro-zone, minimizing the legal obstacles at the EU level toward a satisfactory solution of the crisis. ${ }^{247}$

\section{F. Portugal}

While neither the new budgetary rules nor the legal framework of financial stabilization were at issue in Portugal, the Portuguese Constitutional Tribunal (Tribunal Constitucional) recently delivered several decisions dealing with the legality of measures adopted in response to the Euro-crisis. In the framework of the Program of Financial and Economic Assistance that Portugal negotiated with the EU Commission, the ECB and the IMF to obtain financial aid, ${ }^{248}$ the Portuguese government enacted a series of domestic budgetary measures, aimed at reducing state deficit and improving the economic outlook of the country, which were subject to review by the Constitutional Tribunal. While these measures were technically national, they were in reality enacted by Portugal upon demand of the EU and international institutions, and reflected the policy strategy (embedded in the principle of conditionality of the mechanisms of financial assistance such as the ESM) of adjusting the economic outlook of the country pursuant to the action plan agreed upon in the MoU. In its decisions, however, the Constitutional Tribunal expressed its increasing discontent for the effects that these domestic measures would produce on domestic guarantees, such as the principles of equality and the protection of social rights, enshrined in the Portuguese Constitution.

On July 5, 2012,249 the Constitutional Tribunal, upon referral of the parliamentary opposition, ruled on the constitutionality of a provision adopted in the budget law for 2012, suspending payment of the thirteenth and fourteenth monthly salary for public sector employees. ${ }^{250}$ The Constitutional Tribunal acknowledged that the measure under scrutiny was adopted under exceptional circumstances, in the framework of the MoU signed by the EU Commission, the $\mathrm{ECB}$, and the IMF 251 "as a condition for the obtainment of the loans accorded by the EU and the IMF." 252 Nevertheless, it reviewed the measure for its compatibility with the principle of equality, which required that the government treat "similar situations alike and different situations differently, subject to the

247. See also Bruno de Witte \& Thomas Beukers, The Court of Justice Approves the Creation of the European Stability Mechanism Outside the EU Legal Order: Pringle, 50 COMMON MARKET L. REV. 805 (2013).

248. See Portugal: Memorandum of Understanding on Specific Economic Policy Conditionality, May 3, 2011, available at http://economico.sapo.pt/public/uploads/memorandotroika _04-05-2011.pdf (last visited May 10, 2013).

249. Pt. Const. Ct., Acórdão $N^{\circ}$ 353/2012, judgment of 5 July 2012 [hereinafter: Pt. Const. Ct., judgment of 2012].

250. Lei do Orçamento de Estado, $\mathrm{n}^{\circ}$ 64-B/2011, (budget law for 2012).

251. Pt. Const. Ct., judgment of 2012, $\$ 2$.

252. Id. § 3 (my own translation) ("os quais condicionam a concretização dos empréstimos faseados acordados com a União Europeia e com o Fundo Monetário Internacional.”). 
principle of proportionality." ${ }^{253}$ Because the reduction of the monthly salaries only affected the employees of the public sector, leaving untouched those of the private sector, the Tribunal found that the provisions of the budget law failed to comply with the principle of proportionality. As the Tribunal stated:

The need to adopt measures to address in an effective manner the crisis, cannot be the basis to exempt the legislature from respecting fundamental rights and the principles of the Rule of Law, notably the principles of equality and proportionality. The Constitution is certainly not blind to the economic and financial reality and especially to a situation that may be considered of great difficulty. But it possesses a specific normative force that prevents economic and financial objectives from prevailing, without limits, on the principles such as equality, which the Constitution defends and must accomplish. 254

Yet, having found the measure under scrutiny unconstitutional, the majority of the Constitutional Tribunal decided to suspend the effect of its ruling for 2012. Pursuant to Article 282(4) of the Portuguese Constitution, in fact, the Tribunal can delay the effects of its decisions ${ }^{255}$ - a possibility that came in handy under the circumstances, given "the exceptional public interest" of the Portuguese state, the current context of grave emergency, and the need to continue to keep open access to external financial aid. ${ }^{256}$

The Constitutional Tribunal, however, did not accommodate the arguments of the government in subsequent rulings. Upon referral of the President of the Republic and by the opposition party, the Constitutional Tribunal delivered a decision on April 5, 2013, which declared, this time with immediate effects, the unconstitutionality of several provisions of the budget law for 2013. ${ }^{257}$ Much like the budget law of 2012, the budget law of 2013 - which had been agreed upon by the Portuguese government with the EU Commission, ECB and IMFincluded provisions aimed at containing government deficit by, among other things, a reduction of the stipends and a suspension of the thirteenth and

253. Id. § 5 (my own translation) ("tratem por igual as situações substancialmente iguais e que, a situações substancialmente desiguais se dê tratamento desigual, mas proporcionado.”).

254. Id. § 6 (my own translation) ("A referida situação e as necessidades de eficácia das medidas adoptadas para lhe fazer face, não podem servir de fundamento para dispensar o legislador da sujeição aos direitos fundamentais e aos princípios estruturantes do Estado de Direito, nomeadamente a parâmetros como o princípio da igualdade proporcional. A Constituição não pode certamente ficar alheia à realidade económica e financeira e em especial à verificação de uma situação que se possa considerar como sendo de grave dificuldade. Mas ela possui uma específica autonomia normativa que impede que os objetivos económicos ou financeiros prevaleçam, sem quaisquer limites, sobre parâmetros como o da igualdade, que a Constituição defende e deve fazer cumprir.").

255. See Const., art. 282(4) (Pt.) (stating that "[w]hen required for the purposes of legal certainty, reasons of fairness or an exceptionally important public interest, the grounds for which shall be given, the Constitutional Court may rule that the scope of the effects of the unconstitutionality or illegality shall be [...] restricted").

256. Pt. Const. Ct., judgment of 2012, § 6 (my own translation). ("un objetivo de excecional interesse publico").

257. Pt. Const. Ct., Acórdão N 187/2013, judgment of Apr. 5, 2013 [hereinafter: Pt. Const. Ct., judgment of 2013]. 
fourteenth monthly salary of public employees. ${ }^{258}$ While the Constitutional Tribunal upheld a plurality of measures adopted in the budget law as falling within the discretionary powers of the government, by drawing on its previous decision of July 2012, it subjected the measure affecting the salary of public employees to a proportionality review aimed at verifying their consistency with the principle of equality. In fact, the Tribunal noticed that, "also for the year 2013 public sector workers will be asked to bear an additional effort [in salary reduction] which is not asked to [...] private sector workers in the same economic conditions." 259 Since the previous case had made clear that this situation did not comply with the principle of proportionality, the Tribunal simply restated its conclusion from 2012, holding that the measure under review "failed to comply with the principle of equality as demanding a proportional sharing of the burden of the public charges." 260 In the same case, the Tribunal also reviewed a provision of the budget law aimed at limiting workers' disease and unemployment benefits and struck it down as violating the minimal protection of social right enshrined in the Constitution. ${ }^{261}$

Moreover, on August 29, 2013, the Constitutional Tribunal struck another blow to the economic adjustment measures carried out by the Portuguese government in the framework of the MoU, by declaring unconstitutional a statute introducing the mobility of public workers for violations of the principle of proportionality and legitimate expectations. ${ }^{262}$ And on December 19, 2013, the Constitutional Tribunal once more blocked parts of the budget law adopted by Parliament for the following fiscal year - and implementing the demands of the "troika" of foreign lenders - holding that the reduction of the pensions of public sector workers infringed the principle of legitimate expectations and was therefore unconstitutional. ${ }^{263}$

The decisions of the Portuguese Constitutional Tribunal, therefore, signaled the growing unease of the supreme judicial body for the measures that were enacted nationally, but requested by the EU and international institutions to address the Euro-crisis and re-establish the financial standing of the country. ${ }^{264}$ While in its first decision the Constitutional Tribunal aptly made use of the powers it enjoys under the Portuguese Constitution to suspend the effect of its

258. Lei do Orçamento de Estado ${ }^{\circ}$ 66-B/2012 (budget law for 2013).

259. Id. $\S 40$ (my own translation) ("para o ano de 2013, continuará a exigir-se de quem recebe remunerações salariais de entidades públicas um esforço adicional que não é exigido aos [...] titulares de rendimentos idênticos provenientes do trabalho, no âmbito do setor privado.").

260. Pt. Const. Ct., udgment of 2013, § 45 (my own translation) ("desrespeita o princípio da igualdade proporcional e da justa repartição dos encargos públicos”).

261. Id. §95.

262. Pt. Const. Ct., Acórdão $\mathrm{N}^{\circ}$ 474/2013, judgment of Aug. 29, 2013.

263. Pt. Const. Ct., Acórdão No 862/2013, judgment of Dec. 19, 2013.

264. See Fabrizio Galimberti, Se anche il potere giudiziario critica il rigore, IL SOLE 24 ORE, Apr. 7, 2013, at 10 (discussing the implications of the ruling by the Portuguese Constitutional Court). 
ruling of unconstitutionality, de facto giving a one-off free-pass to the legislation adopted by the government, in subsequent decisions the Tribunal did not refrain from declaring several provisions of the budgetary law to be in violation of the Constitution and therefore immediately void. By interpreting in an activist manner the principle of equality and the guarantees of the protection of social rights of the Portuguese Constitution the Constitutional Tribunal placed heavy limits on the capacity of the national executive and legislature (and, indirectly, of the EU and international institutions coordinating the rescue measures of Portugal) to respond adequately to the fiscal crisis. ${ }^{265}$ With its jurisprudence, therefore, the Tribunal signaled that the future of at least one of the central features of the legal responses to the Euro-crisis, that concerning the economic adjustment measures that debtor countries shall adopt as a condition to obtain financial support, may be standing on shaky ground.

III.

\section{Judicial Review and the Political Process in a Comparative PERSPECTIVE}

The previous Part analyzed decisions by courts at both the national and supranational level reviewing the legality of various components of the new EMU fiscal regime. Building on that detailed analysis of the case law, this Part attempts to identify a trend of increasing judicial involvement in fiscal affairs, to explain its rationale and to critically evaluate it by discussing the relationship between judicial review and the political process in the fiscal and economic domain. Needless to say, a comparison of judicial decisions dealing with aspects of the new architecture of the EMU should be undertaken with some caveats: the nature of the specific measure under review and the scope of the scrutiny carried out by courts differed from one jurisdiction to another, and reflects differences in procedural powers, modes of legal reasoning, and conceptions of the role of the judiciary in a constitutional system. ${ }^{266}$ Yet, an overview of judicial decisions in systems that are as varied as Estonia, France, Germany, Ireland, Portugal, and the EU can provide important insights on how, regardless of the many differences between the various case studies, courts have so far reacted similarly to the reforms of the EMU by expanding significantly their powers to review,

265. For a criticism of the case law of the Constitutional Tribunal also from the point of view of Portuguese constitutional law see Gonçalo de Almeida Ribeiro, Judicial Activism Against Austerity in Portugal, INT'L J. CONST. L. BLOG, Dec. 3, 2013 available at www.iconnectblog.com/2013/12/judicial-activism-against-austerity-in-portugal/.

266. See, e.g., Jan Komarek, Judicial Lawmaking and Precedent in the Supreme Courts: the European Court of Justice Compared to the US Supreme Court and the French Court de Cassation, 11 CAMBRIDGE YBK EuR. LEG. ST. 399 (2009) (comparing reasoning based on precedents); Jacco Bomhoff, Balancing, the Global and the Local: Judicial Balancing as a Problematic Topic in Comparative (Constitutional) Law, 31 HASTINGS INT'L \& COMP. L. REV. 555 (2008) (discussing differences in the way in which courts use the technique of judicial balancing). 
and possibly void, measures adopted by the political branches in the fiscal and economic domain. ${ }^{267}$

As I will report, ${ }^{268}$ a broad-brush assessment of judicial rulings in the field of budgetary constraints, financial stabilization, and economic adjustment reveals that, by and large, courts have validated the new policies followed by the EU institutions and member states in response to the Euro-crisis. Yet, closer scrutiny also reveals that courts have expressed more discomfort when reviewing measures concerning financial stabilization and economic adjustment and that, in a diachronic perspective, this discomfort has gradually grown bigger-with some final decisions even striking down the measures under review. How can we make sense of this development? And how should we evaluate it? As I argue, ${ }^{269}$ the main explanation for the rising tide of judicial intervention in the field of the EMU lies, paradoxically, in the choice by the member states to respond to the Euro-crisis with an intergovernmental approach and with legal measures adopted mainly outside the legal framework of the EU. In a context of intergovernmental governance, courts have found more leeway to become enmeshed in the scrutiny of states' measures than what would have been possible had the member states acted within the EU legal order. In fact, as I shall point out, the paradoxical degree of judicial involvement in EMU affairs generated by an intergovernmental response to the Euro-crisis is made all the more evident when compared with the role that courts have, over the last eighty years, played in the United States - a system where the judiciary enjoys almost unparalleled powers of review.

Hence, the analysis of judicial review of legal measures adopted so far in responses to the Euro-crisis yields an important suggestion: if the political branches want to minimize the scope for judicial overreach, in the future they should respond to the Euro-crisis by working within the framework of the EU. As I will claim, ${ }^{270}$ in fact, judicial involvement in the fiscal domain raises a number of constitutional concerns. The political branches have greater expertise and instrumental capacity than courts to make decisions in fiscal matters. At the same time, in this context, the political process is better able to represent the voice of the people and does not seem to be subject to a structural bias against insular minorities, which would justify greater oversight by courts on rightsprotecting grounds. However, these considerations do not absolve the EU political process from the need of further reforms. Indeed, the legitimacy and democracy of the EU political process urgently need to be improved. But these

267. On the analytical value connected to the "most-different-cases" logic of comparison see Hirschl, supra note 69. See also generally PRACTICE AND THEORY IN COMPARATIVE LAW (Maurice Adams \& Jacco Bomhoff eds., 2012).

268. See infra Part III.A.

269. See infra Part III.B.

270. See infra Part III.C. 
reforms require increasing responsiveness and accountability of the EU political process, rather than increasing review and interference by courts. ${ }^{271}$

\section{A. Identifying the Trend: Increasing Judicial Involvement Across Europe}

Based on the analysis undertaken above, it is possible to identify a trend of judicial involvement in fiscal matters across Europe. Table 1 summarizes this state of affairs by reporting (in the vertical column) the countries whose courts have been considered as case studies and (in the horizontal column) the measures that have been subject to review. At first glance, it is noticeable how often courts have been called to adjudicate pieces of the new constitutional architecture of the EMU. In terms of the effects of the decisions, as the previous Part has made clear, courts have, by and large, validated the new legal measures adopted in response to the Euro-crisis. This is reflected in the rate of "approvals" reported in Table 1. National and supranational courts have given their green light to the enactment and entry into force of a variety of legal measures aimed at strengthening budgetary discipline, introducing new mechanisms of financial stabilization, and prescribing strict programs of economic adjustment. With the exception of the latest decisions of the Portuguese Constitutional Court (discussed below), the rulings analyzed above have validated the legal measure under review. A broad-brush assessment of the role of courts in the framework of the new EMU constitution seems to suggest, therefore, that the judiciary has deferred to the political branches, upheld their action and provided them with leeway in devising responses to the Euro-crisis.

271. See infra Part IV. 
TABLE 1

Courts' rulings dealing with selected aspects of the new the fiscal constitution of EMU: indicating approval or rejection of the measure under review (2012-2013)*

\begin{tabular}{|c|c|c|c|c|c|c|c|}
\hline & \multicolumn{2}{|c|}{$\begin{array}{c}\text { Budgetary } \\
\text { rules }\end{array}$} & \multicolumn{3}{|c|}{ Financial stability } & \multicolumn{2}{|c|}{$\begin{array}{c}\text { Econ. } \\
\text { adjustment }\end{array}$} \\
\hline & $\begin{array}{c}\mathrm{EU} \\
\text { legislation }\end{array}$ & $\begin{array}{c}\text { Fiscal } \\
\text { Compact }\end{array}$ & EFSF & $\begin{array}{c}\text { Amendment } \\
\text { Art. } 136 \\
\text { TFEU }\end{array}$ & ESM & $\begin{array}{c}\text { Budget } \\
\text { law for } \\
2011\end{array}$ & $\begin{array}{c}\text { Budget } \\
\text { law for } \\
2012\end{array}$ \\
\hline Estonia & - & - & - & - & Approved & - & - \\
\hline France & - & Approved & - & - & - & - & - \\
\hline Germany & - & Approved & Approved & Approved & $\begin{array}{l}\text { Approved } \\
\text { (with } \\
\text { conditions) }\end{array}$ & - & - \\
\hline Ireland & - & - & - & Approved & Approved & - & - \\
\hline ECJ & - & - & - & Approved & Approved & - & - \\
\hline Portugal & - & - & - & - & - & Approved & Rejected \\
\hline
\end{tabular}

*The mark (-) indicates that the court has not ruled on the issue.

Nevertheless, if we include a qualitative analysis of the courts' reasoning, it is evident that judicial support for the new fiscal constitution of the EMU has been much less enthusiastic. This emerges not only from decisions such as those of the German Constitutional Court or the Portuguese Constitutional Tribunal, which placed explicit limits on the validity of the measures under review, or by 
the preliminary reference of the Irish Supreme Court, which suggested worries about the legality of the ESM Treaty. It also emerges from the case law of the Estonian Supreme Court and the French Constitutional Council, which appeared, overall, to embrace a Europarechtsfreundliche approach. ${ }^{272}$ In fact, while the decision of the Estonian Supreme Court is certainly one of the more open toward the constitutional reforms undertaken in the EU in response to the Euro-crisis, the judgment was delivered by a harshly divided court, with nine judges out of nineteen fundamentally objecting to the wisdom of the decision, and one judge (casting the decisive ballot for the majority) arguing that the case ought to have been dismissed on procedural grounds. Similarly, the French Constitutional Council, while largely upholding the Fiscal Compact, added several réserves d'interprétation which potentially restrict (although it is yet unclear with what legal effects) the scope of the EMU reform. ${ }^{273}$

Specifically, two main features seem to emerge from a qualitative analysis of courts' decision in the fiscal arena. First, judicial institutions have generally been supportive of new EMU measures introducing tighter budgetary constraints, but have expressed more discomfort towards measures of financial stabilization and economic adjustment. Hence, while neither the French Conseil Constitutionnel nor the German Bundesverfassungsgericht raised fundamental objections to the ratification of Fiscal Compact, the latter put important caveats on the ESM Treaty - which recalled analogous skepticism in the dissenting opinions of the Estonian Supreme Court and in the preliminary reference of the Irish Supreme Court to the ECJ. At the same time, of course, the Portuguese Constitutional Court repeatedly underlined the problematic aspects of the budgetary legislation adopted to implement domestically the economic adjustment program agreed to by Portugal and the troika.

Second, while courts have overall backed the responses to the crisis devised by the EU member states and institutions, over the years courts have also revealed a greater unwillingness to let political branches have it their way. This evolution in judicial approach is, of course, evident in the case law of the German Constitutional Court: in its September 2011 decision, the Court validated, albeit with its customary lecturing tone, the Bundestag's approval of the German guarantees to the EFSF without putting any specific condition on this. But in September 2012, it demanded ratification of the ESM Treaty to be accompanied by two binding declarations under international law, clarifying for

272. The notion of Europarechtsfreundlichkeit-literally meaning: "friendship toward European law"-finds its origin in German constitutional law. On this see Jacques Ziller, Zur Europarechtsfreundlichkeit des deutschen Bundesverfassungsgerichtes. Eine ausländische Bewertung des Urteils des Bundesverfassungsgerichtes zur Ratifikation des Vertrages von Lissabon, 65 ZÖR 157 (2010) (discussing the notion of openness toward EU law in the judgment of the German Constitutional Court relating to the ratification of the Lisbon Treaty).

273. Moreover, the Constitutional Council took the opportunity of the case to strengthen its powers vis-à-vis the political branches in the fiscal domain, a step with potential implications for the future. See supra note 135 . 
the avoidance of any doubt the maximum limit of German contribution to the ESM fund and the enduring right of the Bundestag to access documents handled by the ESM institutions, despite the duty to protect confidential information by ESM bodies.

The case of the Portuguese Tribunal Constitucional, however, epitomizes this judicial shift: as the length of the Euro-crisis, and arguably the harshness of the measures of economic adjustment adopted to tackle it grew, the Constitutional Tribunal became more impatient toward the action of the political branches. In its first ruling from July 2012 (soon after Portugal had entered into a program of financial assistance with the EU and the IMF), the Court resorted to procedural powers it enjoys under the Portuguese Constitution to suspend the effect of a decision of unconstitutionality of a budget law for violation of the principles of equality and proportionality. Nine months later, in April 2013, however, the Court did not refrain from striking down another identical measure. And in August 2013, and then December 2013 the Court struck a few other blows to the economic policy of the Portuguese government, leaving it in the very difficult situation of having to find new revenue sources for its budget. These decisions signaled that the emergency conditions that had justified restrictions of constitutional principles could not be extended forever and shed some pessimistic light on the willingness of courts - in Portugal but perhaps also elsewhere-to uphold those parts of the new fiscal constitution of the EMU requiring the adoption of tough measures of economic adjustment for countries under financial assistance. ${ }^{274}$

A number of economic and institutional reasons may explain these two dynamics. On one side, it is plausible that courts face fewer incentives to oppose budgetary constraints (such as those dictated by the Fiscal Compact) that demand only negative action by their governments in the future. In contrast, they adopt a heightened scrutiny vis-à-vis either measures of financial stabilization (like the ESM Treaty), which require positive action by the states in the form of financial contributions, or measures of economic adjustment (as those agreed under the MoUs), which require immediate implementation. ${ }^{275}$ At the same time, while courts may actually benefit from the introduction of budgetary rules, by seeing their institutional position vis-à-vis the political branches strengthened, ${ }^{276}$ they can perceive a threat from the adoption of measures of economic adjustment or financial stabilization which restrict fundamental social rights (either because of the austerity measures to be adopted in the

274. See Euro Wobbles. Portugal's Constitutional Court Creates New Problem for the Euro, THE ECONOMIST, Apr. 13, 2013 (discussing the decision of the Portuguese Constitutional Court in context).

275. See Alicia Hinarejos, The Euro Area Crisis and Constitutional Limits to Fiscal Integration, CAMBRIDGE YBK EUR. LEG. ST. (2011) (underlying greater easiness in the integration of budgetary rules, compared to the integration of other fiscal policies which have redistributive effects)

276. See Fabbrini, supra note 23, 22. 
implementation of an economic adjustment program, or because of the reduced capacity of the state budget to provide social protections due to the contributions to a stability fund). ${ }^{277}$ Since a core function of courts in constitutional regimes is to protect rights, taking this task seriously even in the face of economic emergencies may be perceived by courts as a necessary step to consolidate their position in the constitutional system. ${ }^{278}$

On the other side, the increased uneasiness of courts vis-à-vis several aspects of the new fiscal constitution of the EMU may be the result of economic and institutional factors. While in the aftermath of an economic emergency courts may trust policy-makers to have better knowledge of how to handle the crisis and therefore be more willing to let them take decisions, over time courts raise the threshold of legality that political branches must respect in order for their action to pass judicial muster. ${ }^{279}$ Because the Euro-crisis, and the attempts to address it, have lasted for more than five years now, courts may become less concerned with the economic risk that their decisions could produce, and therefore turn more vocal in expressing their discontent to the policy strategies followed by the EU institutions or member states. At the same time, courts may be more willing to intervene and sanction alleged illegalities in the measures adopted to reform the EMU legal architecture as they perceive the political process - that is, the set of procedures by which representative institutions adopt decisions - to be malfunctioning. ${ }^{280}$

$\mathrm{Be}$ that as it may, the previous analysis yields a central conclusion: regardless of the political, economic, or legal characteristic of the cases considered, the judiciary has acquired an extensive and pervasive influence in the fiscal and economic domain. This state of affairs is also reflected in the great preoccupation with which policy-makers and financial markets alike have awaited most of the judgments considered above. ${ }^{281}$ In some cases, e.g. in Estonia or France, the rulings of courts were technically not essential for the entry into force of the measure under review, but, rather, affected the capacity of the state to become a party to the challenged treaty. ${ }^{282}$ In others, however, the

277. See Est. Sup. Ct., ESM judgment, §§ 165-66 (emphasizing the importance of a wellfunctioning economy for the protection of fundamental rights); Pt. Const. Ct., judgment of 2013, $\S$ 92-95 (discussing restrictions on pre-existing minimum protections of social rights).

278. See Mark Tushnet, Weak Courts, Strong Rights: Judicial Review and Social WELFARE RigHTS IN COMPARATIVE CONSTITUTIONAL LAW (2008).

279. See ceteris paribus, Federico Fabbrini, The Role of the Judiciary in Times of Emergency: Judicial Review of Counter-Terrorism Measures in the United States Supreme Court and the European Court of Justice, 28 Ox. YBK EUR. L. 664 (2009) (explaining how courts are more deferent to the political branches in the aftermath of a national security emergency, but that they become more demanding in their scrutiny as time goes by).

280. See infra text accompanying notes 315,316 .

281. See, e.g., European Economics Strategy: Concerns about the German Constitutional Court, Morgan Stanley report, Aug. 30, 2012 (emphasizing major financial risks if the German Constitutional Court strikes down the ESM Treaty).

282. The Fiscal Compact, art. 14(2) required the ratification of only twelve member states of 
decisions of courts such as the Bundesverfassungsgericht or the ECJ have kept all the relevant stakeholders waiting with bated breath, by threatening to invalidate a whole scheme of regulation adopted to respond to the Euro-crisis. In conclusion, a clear trend of rising judicial involvement in fiscal affairs seems to emerge throughout Europe.

\section{B. Explaining the Trend: the Intergovernmental Method and its Outcomes}

How can we make sense of this trend of judicial involvement in the fiscal domain across Europe? The main explanation for this trend lies, in my view, in the overall strategy pursued by the EU member states in responding to the Eurocrisis. As Part I indicated, while a number of reforms to the architecture of EMU have been carried out in the framework of EU law, the member states have decided to act to a large extent outside the EU legal order, tightening budgetary constraints, establishing new mechanisms of financial stability, and setting up a framework for economic adjustment for countries in fiscal troubles through international agreements. This strategy is consistent with an intergovernmental model for the management of the Euro-crisis, which has stressed the centrality of national governments (in the European Council) and their freedom to act through agreements outside EU law, rather than the centrality of the EU institutional machinery and the potentials of EU law to address the crisis. As Sergio Fabbrini has argued: "The extremely complex system of economic governance set up during the euro crisis [...] has been largely motivated and defined on the basis of the intergovernmental logic and decided through and within the intergovernmental institutional framework." 283

Yet, responding to the Euro-crisis through an intergovernmental approach has come with a high price in terms of judicialization. ${ }^{284}$ As made clear at the beginning of Part II, ${ }^{285}$ in most state jurisdictions, supreme or constitutional courts are empowered to review a priori international treaties. On the contrary, it is a core principle of EU law that national courts cannot review the legality of EU legislation: national courts can refer a preliminary question to the ECJ, but only the ECJ can declare an EU act void. ${ }^{286}$ Actually, this state of affairs is

the Euro-zone, out of seventeen for its entry into force, while the ESM Treaty, art. 48 required ratification by a number of states whose initial subscription to the capital of the ESM amounted to no less than 90 percent of the ESM capital. As a result, ratification of the Fiscal Compact by France or of the ESM Treaty by Estonia was not a conditio sine qua non for the entry into force of these two agreements. For a discussion of the lack of unanimous ratification in the entry into force of the Fiscal Compact see Carlos Closa Montero, Moving Away from Unanimity: Ratification of the Treaty on Stability, Coordination and Governance in the Economic and Monetary Union 1, 11 RECON Working Paper No. 2011/38.

283. See Sergio Fabbrini, Intergovernmentalism and Its Outcomes: The Implications of the Euro Crisis on the European Union, COMPARATIVE POLITICAL STUDIES 1, 2 (2013).

284. See Shapiro \& Stone Sweet, supra note 5, at 71.

285. See supra text accompanying note 58.

286. Case 314/85, Foto-Frost, [1987] E.C.R. I-4199 (holding that only the ECJ can quash EU legislation). 
captured well by Table 1 above. As Table 1 makes clear, in fact, legislation adopted in the EU legal framework has entirely escaped judicial review. This is the case both for the Six Pack and Two Pack (introducing tighter budgetary rules), and for the EFSM (setting up a mechanism of financial stabilization). ${ }^{287}$ On the contrary, courts have been asked on multiple occasions to adjudicate international agreements such as the Fiscal Compact, and the ESM (or the European Council Decision amending Article 136(3) of the TFEU).

At the same time, courts have been asked to review domestic policies implementing measures of economic adjustment agreed through international agreements-witness the Portuguese Constitutional Tribunal's review of budgetary laws in 2012 and 2013. Of course, technically these measures were domestic bills adopted by the Portuguese legislature. Yet, it does not go unnoticed that their content largely reflected what the Portuguese government and the troika had agreed to in the MoU. In fact, however, a MoU is nothing more than a contractual agreement, under public international law, between a debtor state and its international lenders to obtain financial assistance in exchange for economic reforms. ${ }^{288}$ As such, we are dealing, once again, with an international agreement adopted outside the framework of EU law and pragmatically devised to commit a member state to a program of economic adjustment perceived as necessary to address its fiscal troubles. In this situation, the shift "from legislation to contract" 289 also implied that the relevant domestic court found itself empowered to review the national measure implementing the $\mathrm{MoU}$ in a way which would have been unlikely had the measure under review been grounded in EU law stricto sensu.

Resort by the member states to international agreements outside the EU legal order is in itself nothing new. ${ }^{290}$ However, it is argued here a contrario that, if legal measures to respond to the Euro-crisis had been adopted through ordinary EU legislation, they would have been untouchable by national courts, save by raising a preliminary reference to the ECJ. As several scholars have underlined, in fact, EU law potentially offered room for the adoption of these measures as EU legislation. ${ }^{291}$ In the case of the Fiscal Compact, enhanced cooperation provided the ideal framework for enacting the substantive measures

287. See supra notes 16,17 , and 32 .

288. See Papadopoulou, supra note 62.

289. See Paul Craig, Economic Governance and the Euro Crisis: Constitutional Architecture and Constitutional Implications, in THE CONSTITUTIONALIZATION OF EuROPEAN Budgetary CONSTRAINTS 19 (Maurice Adams, Federico Fabbrini \& Pierre Larouche eds., 2014).

290. See also Bruno de Witte, International Treaties on the Euro and the EU Legal Order (2012) (unpublished manuscript on file with author) (underlying how resort to international treaties adopted outside the EU legal order proper has a long pedigree in the history of EU integration).

291. See, e.g., Angelos Dimopoulos, The Use of International Law as a Tool for Enhancing Governance in the Euro Area and its Impact on EU Institutional Integrity, in THE CONSTITUTIONALIZATION OF EUROPEAN BUdGETARY CONSTRAINTS 41 (Maurice Adams, Federico Fabbrini \& Pierre Larouche eds., 2014). 
codified therein. ${ }^{292}$ In the case of the ESM, arguably Article 122(2) of the TFEU - which allows the EU to provide financial assistance "[w]here a Member State is having difficulties or is seriously threatened with severe difficulties caused by natural disasters or exceptional occurrences beyond its control"offered a sufficient legal basis to enact a mechanism to stabilize the Euro-zone in the framework of EU law. ${ }^{293}$ After all, this clause was considered a legitimate basis for the EFSM, so political considerations more than legal arguments seemed to trump recourse to this clause as a basis for the ESM. ${ }^{294}$ Finally, in the case of the measures of economic adjustment included in the MoU, it could be argued that a directive (or, possibly, another EU binding legal measure pursuant to Article 136 of the TFEU) could have been employed to demand structural reforms to a member state through an instrument firmly grounded in EU law. ${ }^{295}$

Hence, the choice by the EU member states to respond to the Euro-crisis through a strategy of intergovernmental governance, and with systematic recourse to international agreements outside the EU legal order, has resulted in increasing judicial involvement in fiscal affairs. In the context of the new constitutional architecture of the EMU, courts have found ample leeway to become involved in the adjudication of measures adopted so far to tackle the Euro-crisis. The limits of intergovernmentalism in managing the Euro-crisis

292. See Federico Fabbrini, Enhanced Cooperation Under Scrutiny, 40 LEG. ISSUES OF ECON. INTEGR. 197 (2013) (explaining how the option to resort to enhanced cooperation was open for the adoption of the Fiscal Compact but that member states resorted to a treaty mainly for political reasons). See also Anna Kocharov et al., Another Legal Monster? An EUI Debate on the Fiscal Compact, (EUI Working Papers Law No. 09 2012).

293. See supra note 31. See also Roland Bieber, Observer - Policeman - Pilot? On Lacunae of Legitimacy and the Contradictions of Financial Crisis Management in the European Union, 18 (EUI Working Papers Law No. 16 2011) (explaining that, if Article 122 of the TFEU was a sufficient basis for assistance to Greece in 2010, it could have been used also in subsequent rescue measures and that therefore there was no need to amend Article 136(3) of the TFEU to empower the states to establish, outside the EU framework, the ESM).

294. A major problem connected to the use of Article 122 TFEU for the creation of a stability mechanism in the framework of EU law is due to the fact that, pursuant to that provision, money for the mechanism would have to be appropriated from the EU budget. As it is well known, the EU budget is currently razor thin - so it would have been impossible to establish a stability mechanism with a "firepower" of 700 billion Euros, i.e. the size of the ESM. However, it is remarkable to notice that almost at the same time in which the member states debated the creation of the ESM outside EU law, the renewal of the EU multi-annual financial framework was at stake in the context of the EU. Member states could have therefore increased their contributions to the EU budget (so that it could support an EU stability mechanism), instead of diminishing - as they did-the EU budget and simultaneously contributing outside the EU framework to the capital of the ESM. See Hélène Mulholland, David Cameron Vows to Fight EU Budget Increase, THE GuARDIAN, Oct. 27, 2010 (outlining interconnections between EU budget fights and the ESM).

295. See Article 288 TFEU (stating that "[a] directive shall be binding, as to the result to be achieved, upon each Member State to which it is addressed, but shall leave to the national authorities the choice of form and methods.") and Article 136 TFEU (stating that "[i]n order to ensure the proper functioning of economic and monetary union, and in accordance with the relevant provisions of the Treaties, the Council shall [...] adopt measures specific to those Member States whose currency is the euro."). 
effectively and legitimately have been emphasized repeatedly. ${ }^{296}$ This Article joins this chorus but from another perspective, underlining how an intergovernmental approach to the Euro-crisis also generated growing judicialization. In the next subsection I will discuss why this development should be evaluated with some skepticism. What I would like to point out now, instead, is how the degree of judicial involvement taking place in the new EMU institutional architecture is paradoxical. One of the central tenets of intergovernmentalism in EU governance is that the executive branches (acting within the European Council) will dominate decision-making to the detriment of legislatures and courts. ${ }^{297}$ Yet, the outcome of intergovernmentalism has been an increasing involvement of courts - in a way which would have been impossible had the member states acted through the Community method..$^{298}$

Comparative law provides the best evidence of how paradoxical the deep involvement of the national and supranational courts in the EU in the field of economic governance is. In fact, the degree of involvement of courts in EMU affairs (with the latest judicial rulings in Germany and Portugal restricting severely, or striking down tout court, legislation adopted in the economic domain) is far greater than what one finds even in a country such as the United States, which is generally credited as having one of the strongest systems of judicial review world-wide. ${ }^{299}$ If one considers the case of the US, it is remarkable to notice how small a role the judiciary has played over the last eighty years in the field of fiscal and economic policy. Since the New Deal, a central tenet of both state and federal courts has been to defer widely to the political branches in matters dealing with the economy, the budget, and fiscal rules. As famously signaled by the US Supreme Court in the Carolene Products case, ${ }^{300}$ courts are to adopt a more exacting scrutiny in matters dealing with individual rights, where the political process is unable to internalize the interests of insular minorities, while giving legislative determinations in matters of economic affairs broad deference. ${ }^{301}$

The retreat of courts from the arena of economic governance was the result of a long fought battle by the political branches over judicial overreaching. ${ }^{302}$

296. See from various perspectives JÜRGEN HABERMAS, THE CRISIS OF THE EUROPEAN UNION (2012), DANIEL COHN-BENDIT \& GUY VERHOFSTADT, FOR EUROPE (2012), and SYLVIE GOULARD \& MARIO MONTI, DE LE DÉMOCRATIE EN EUROPE (2013).

297. See, e.g., Ben Crum, Saving the Euro at the Cost of Democracy?, 51 J. Cомм. Mкт ST. 614 (2013) (speaking of a form of executive federalism).

298. See supra Table 1.

299. See Tushnet, supra note 275,21 (stating that "[t]he modern articulation of strong form judicial review is provided [by] the US Supreme Court [which] described the federal courts as "supreme in the exposition of the law of the Constitution" and inferred from that a duty of the legislature to follow the Court's interpretation.").

300. United States v. Carolene Products, 304 U.S. 144 (1938).

301. See Bruce Ackerman, We the People. Volume 1. Foundations ch. 5, (1991).

302. See JefF Shesol, Supreme Power: Franklin Roosevelt vs. THE Supreme Court (2010). 
From the early 1900s until after the Great Depression, courts had systematically hampered the capacity of the state and federal governments to manage the economy and adopt adequate policy responses to the crisis of 1929, by interpreting the US Constitution as embracing a specific economic theory. ${ }^{303}$ Most famously, in the Lochner case, ${ }^{304}$ the US Supreme Court read the Due Process Clause of the Fifth and Fourteenth Amendments as enshrining a substantive commitment to free market and free contract, and thus largely imposed a laissez-faire reading of the Constitution that prevented the US government from taking action in the economic and social sphere. ${ }^{305}$ However, as is well-known, the FDR revolution, and the threat to change the composition of the US Supreme Court, eventually prompted the judiciary to change course and validate the New Deal transformation of the US (institutional and economic) Constitution. ${ }^{306}$ Since then, it has been customary for US courts to back-off from reviewing legislation that has economic implications on the assumption that the "[C]onstitution is not intended to embody a particular economic theory."307

The most explicit declaration of judicial retreat from the adjudication of economic questions, which are better left to the judgment of the political branches of government, can be found in the 1942 decision of Wickard $v$. Filburn. ${ }^{308}$ In this case the Supreme Court upheld a federal regulation on agricultural production stating that economic affairs "are wisely left under our system to resolution by the Congress under its more flexible and responsible legislative process. Such conflicts rarely lend themselves to judicial determinations. And with the wisdom, workability and fairness of the plan of regulation we have nothing to do." ${ }^{309}$ This tradition of judicial restraint has largely survived until today. Arguably this was confirmed in the June 2012 decision by the US Supreme Court in the case of National Federation of Independence Business $v$. Sebelius, ${ }^{310}$ which dealt with the single most important piece of economic legislation in decades: the Affordable Care Act. Although in a ruling which was not exempted from criticism, ${ }^{311}$ the Supreme

303. For further literary references on the New Deal see Federico Fabbrini, Europe in Need of a New Deal: On Federalism, Free Markets and the Right to Strike, 43 GEORGETOWn J. INT'L L. 1175, 1215-1217 (2012).

304. Lochner v. New York, 198 U.S. 45 (1905) (striking down a New York statute limiting the hours of work in bakeries). For a thorough historical examination of Lochner, see generally Sidney Tarrow, Lochner v. New York: A Political Analysis, 5 LAB. HIST. 277 (1964).

305. See generally Cass Sunstein, Lochner's Legacy, 87 ColuM. L. Rev. 873 (1987).

306. See Bruce ACKerman, We the People: Volume 2. Transformations (1998).

307. Lochner, at 75 (Holmes J. dissenting).

308. Wickard v. Filburn, 317 U.S. 111 (1942).

309. Id. at 129 (footnotes omitted).

310. Nat'l Fed. of Indep. Bus. v. Sebelius, 567 U.S. _ (2012).

311. See e.g. Ronald Kahn, The Commerce Clause and Executive Power: Exploring Nascent Individual Rights in National Federation of Independent Business v. Sebelius, 73 MD. L. REV. 133 (2013) (discussing the implication of the decision of a five-justice majority to find the Affordable Care Act inconsistent with the Constitution's Commerce Clause). 
Court ultimately upheld the law as an exercise of the federal government's taxing power under the US Constitution and made clear that its task was "not [to] consider whether the Act embodies sound policies. That judgment is entrusted to the Nation's elected leaders." 312

In conclusion, to the extent that the EU institutions and the member states will have to enact new measures to tackle the future challenges emerging in the EMU, the analysis of courts' decisions and the explanation of its rationale provide an important lesson. If the political branches want to minimize the threat of judicial invalidation - a threat that kept policy-makers and financial markets alike waiting with bated breath for most of the judgment described in Part II ${ }^{313}$ - they should develop policies in the framework of the EU legal order and resort to ordinary EU legislation. In this framework, not only is the legitimacy of decision-making at its best (given the involvement of the Commission, the Council and the Parliament, each representing different interests and constituency); ${ }^{314}$ but also the risk of judicial overreach is reduced, with the ECJ as the only court empowered to review the legality of EU laws. ${ }^{315}$ Therefore, utilitarian arguments, if not idealistic concerns, should convince the member states to abandon the intergovernmental framework and resort to the ordinary legislative procedure under the Economic Policy Chapter of the TFEU to enact future reforms of the EMU. ${ }^{316}$

\section{Evaluating the Trend: the Political Process and its Advantages}

Having identified a trend of increasing judicial involvement in fiscal affairs, and explained it in light of the turn toward intergovernmentalism, how should we evaluate this state of affairs? It is my argument that the current high degree of judicial involvement in the fiscal domain should be approached with skepticism. ${ }^{317}$ One could emphasize the practical concerns that this involvement

312. Id. at 2 (Opinion of Roberts C.J.) [of the slip opinion].

313. See supra text accompanying note 271.

314. But see infra Part V.

315. The fact that the ECJ can review EU legislation is a due guarantee of legality. Yet the centralization of the powers of review in a single body-which moreover is subject to checks and balances at the EU level-presents institutional advantages. For further information see Ingolf Pernice, Domestic Courts, Constitutional Constraints and European Democracy: What Solution for the Crisis?, in ThE CONSTITUTIONALIZATION OF EUROPEAN Budgetary CONSTRAinTs 297 (Maurice Adams, Federico Fabbrini \& Pierre Larouche eds., 2014) (explaining how the assessment of the most appropriate ways to tackle the crisis is best done at the European level).

316. See European Parliament resolution of 20 November 2012 with recommendations to the Commission on the report of the Presidents of the European Council, the European Commission, the European Central Bank and the Eurogroup "Towards a genuine Economic and Monetary Union", 2012/2151(INI) at $\S 1$ (calling for the renewal of the governance of the EMU within the institutional framework of the EU).

317. For a more favorable discussion of the role of courts in the context of the Euro-crisis see however Elaine Fahey and Samo Bardutzky, Who got to Adjudicate the EU Financial Crisis and Why?, in THE CONSTITUTIONALIZATION OF EUROPEAN BUdGETARY CONSTRAINTS 341 (Maurice 
may place on future reforms of the EMU at a time when the EU institutions and member states move on to debate new instruments to address the Euro-crisise.g. through a Banking Union and a fiscal capacity for the EMU. ${ }^{318}$ The risk that the over-expansive role of the judiciary may constitute an obstacle to future measures adopted in response to the Euro-crisis is readily visible in the recent quarrel over whether the adoption of the so-called Banking Union-that is, the set of legal measures aimed at creating at the EU level a single bank supervisory mechanism, a common resolution system and a deposit guarantee schemeshould be preceded by a Treaty change. It does not seem far-fetched to argue, in fact, that the requests by the German government to introduce a Treaty amendment before enacting the Banking Union are motivated by fear of judicial invalidation by the German Constitutional Court. ${ }^{319}$

But the real point is that strong constitutional arguments plead in favor of letting the political branches, rather than the courts, take fundamental decisions in the fiscal arena. As Daniel Halberstam has explained, in separation-of-powers systems three main considerations should guide the allocation of competences among alternative institutions: expertise, voice and rights. 320 The first consideration asks which actor has the better claim of knowledge or instrumental capacity to make a decision in a given field. The second asks which actor has the better claim of representing the relevant political will. And the third asks which actor is better placed to protect rights. In the fiscal domain, the first and second considerations (expertise and voice) strongly plead in favor of letting the political branches, rather than the courts, make decisions. At the same time, the third consideration (rights) does not play a fundamental enough role in the economic domain so as to change the balance of institutional capacities in favor of greater judicial involvement.

First, political institutions are endowed with greater expertise than courts in the fiscal domain. ${ }^{321}$ By expertise, I mean the technical knowledge to understand economic phenomena and to take informed decisions on them and the institutional capacity to administer effectively measures which achieve the desired results. ${ }^{322}$ Governments, parliaments, and central banks at the national

Adams, Federico Fabbrini \& Pierre Larouche eds., 2014).

318. For further on this see Federico Fabbrini, From Fiscal Constraints to Fiscal Capacity: The Future of EMU and its Challenges, in THE CONSTITUTIONALIZATION OF EUROPEAN BudgetARy CONSTRAints 399 (Maurice Adams, Federico Fabbrini \& Pierre Larouche eds., 2014).

319. See Alex Barker, Berlin Demands Treaty Change for Bank Reforms, FIN. TIMES, Apr. 14, 2013 (discussing Germany's request for a Treaty change before adopting the Banking Union).

320. Daniel Halberstam, Constitutional Heterarchy: the Centrality of Conflict in the European Union and the United States, in RULING THE WORLD 326, 337 (Jeffrey Dunoff \& Joel Trachtman eds., 2009).

321. See NeIl Komesar, IMPERFECT Alternatives: ChOOSING INSTITUTIONS IN LAW, ECONOMICS AND PUBLIC POLICY (1994) (advising a comparative institutional analysis to identify which institution - the courts, the political process or the market - is better placed to take decision in a given domain).

322. See also Miguel Poiares Maduro, Courts and Pluralism: Essay on a Theory of Judicial 
level, and the Commission, the Council, the Parliament, and the ECB at the supranational level, have the resources and institutional capacity to undertake this activity. Unlike courts-which are generalist institutions, with knowledge mainly in the legal field-political branches work under the support of ad hoc research units, staffed with economists, statisticians and social scientists, which monitor fiscal phenomena, and-through impact assessments and scientific evidence-can predict the effects of specific fiscal policies. Moreover, unlike courts - which are by definition re-active institutions, since they can only respond to legal challenges ${ }^{323}$ - political branches can adopt proactive approaches, aimed at anticipating specific phenomena and creating incentives or disincentives toward virtuous economic results. Finally, unlike courts - which are generally ill equipped with instruments to take decision in the policy fieldpolitical branches can resort to a broad swath of policy and legal measures to achieve their goals.

Second, while the democratic deficit of intergovernmental decision-making in the EU should not be obliterated, and has been in fact magnified by the Eurocrisis ${ }^{324}$ still it appears that political branches enjoy greater voice-meaning the capacity to represent the political will of the people-than courts. ${ }^{325}$ Indeed, recent signs of inter-institutional conflict and democratic contestation reveal some capacity of the EU regime to respond to popular and democratic pressures in the economic domain. A prime example of this dynamic is reflected in the recent decision by the EU Parliament to reject the multi-annual financial framework agreed upon by the European Council which reduced the EU budget for this first time ever. ${ }^{326}$ With this act, in fact, the EU Parliament outlined a political vision alternative to that defended by a majority of member states in the European Council, politicizing fundamental decisions on fiscal issues. ${ }^{327}$ At the

Adjudication in the Context of Legal and Constitutional Pluralism, in RULING THE WORLD 356, 372 (Jeffrey Dunoff \& Joel Trachtman eds., 2009) (discussing the institutional capacity of courts vis-àvis that of other institutions).

323. See Mauro CAPPElletti, Il CONTROllo giUdiziario Di COSTITUZionalità DELle LEGGI NEL DIRITTO COMPARATO 9 (1972) (emphasizing the fact that a legal challenge is the necessary conditions for courts' activity, and that conversely: ubi non est actio, ibi non est jurisdictio).

324. See supra text accompanying note 286.

325. See Peter Lindseth, Of the People: Democracy, the Euro-zone and Lincoln's Threshold Criterion, 22 BERLIN JOURNAL 4, Spring 2012, (emphasizing how, despite the Euro-crisis, the EU features pretty well in terms of input legitimacy and output legitimacy, while being still deficient in demos-legitimacy); Wojciech Sadurski, Democratic Legitimacy of the European Union: A Diagnosis and Some Modest Proposals, 32 POL. YBK OF INT'L L. (2013) (emphasizing mechanisms of direct and indirect democratic legitimacy in the EU).

326. See European Council Conclusions, Feb. 8, 2013, EUCO 37/13 (deciding the size of the future EU budget) and European Parliament Resolution of March 13, 2013 on the European Council conclusions concerning the Multiannual Financial Framework, 2012/2803(RSP) at $\S 1$ (rejecting the agreement of the European Council).

327. See Beda Romano, Strasburgo boccia il budget, IL SOLE 24 ORE, Mar. 14, 2013, at 13 (discussing the political implications of the vote by the European Parliament to reject the budget deal agreed by the European Council). 
same time, one can think of several national elections that, since the outburst of the Euro-crisis, have shifted governmental powers to political coalitions advancing economic agendas which oppose the policies pursued so far in the reform of the EMU.328 Albeit very imperfectly, the EU political process provides a venue for legitimate decision-making that courts can hardly replace.

Third, while of course major weaknesses characterize the EU political process and ought to be addressed in the next institutional reforms of the EMU, it is unclear to what extent the democratic deficit of the EU political process would be cured by greater oversight by institutions like courts, which by definition are non-democratic. ${ }^{329}$ As it is well-known, the counter-majoritarian nature of courts is a valuable asset especially in the protection of fundamental rights, which are claims that individuals must invoke against majority rule. ${ }^{330} \mathrm{As}$ argued by many legal scholars, a crucial constitutional task of courts is to check and review action by the political branches in order to secure the rights of those individuals whose interests the political process is unable to internalize. ${ }^{331}$ In these situations, thanks to their greater capacity to protect rights, courts can correct the distortions produced by the political process and its bias against insular minorities. In the fiscal domain, however, there seems to be no evidence that the political process is biased by structural failures and by the tendency to systematically underrepresent specific interests. In other words, regardless of the content of the legal measures falling under the review of European courts, it seems that in the area of fiscal governance the political process is generally able to internalize the interests of the affected stakeholders and to ensure that no group of citizens has its voice systematically discarded in the policy-making process. As a result, courts should play a restrained role and hold their fire for other fields where instead action is needed to correct the deficiencies of the political process on rights protecting grounds. ${ }^{332}$ This is the legacy of the

328. See Andrew Higgins, Europe Pressed to Reconsider Cuts as Cure, THE NEw YORK TIMES, Apr. 27, 2013 (discussing increased political malaise vis-à-vis the strategy so far adopted to address the Euro-crisis).

329. See also infra text accompanying note 327.

330. On the counter-majoritarian nature of courts see especially ALEXANDER BICKEL, THE LEAST DANGEROUS BRANCH: THE SUPREME COURT AND THE BAR OF POLITICS (1986).

331. See John Hart Ely, Democracy and Distrust: a Theory of Judicial Review (1980); Jesse Choper, Judicial ReVIEW AND the National Political Process (1980).

332. Of course, legal challenges against many features of the new constitutional architecture of the EMU were clothed in rights terms - witness the petitioners before the Bundesverfassungsgericht in the ESM case who claimed that the ESM restricted their right to vote. However, it has been emphasized how, in fact, the Constitutional Court has been skewing its procedural rules in order to adjudicate as fundamental-rights-questions issues which instead concern the structure of powers or the governance of the economy. See Wendel, supra notes 193 and 24. See also the interview to the President of the Bundestag, Karl Lamer: Heriber Prantl, Karl Lamers rügt Verfassungsrichter, SÜDDEUTSCHE ZeITUNG, Sept. 1-2, 2012, at 5, which criticizes the interference by the German Constitutional Court. 
Carolene Products case in the US ${ }^{333}$ but its rationale well applies in the EU context too.

Granted, while in the US courts can defer to a reasonably well functioning political process to take decisions in the economic domain, in the EU the capacity and legitimacy of political institutions is much more questionable. In the US, policy-making decisions are taken by a federal government composed of a directly elected legislature and a President who is responsible to the people at periodic elections. ${ }^{334}$ In the EU, on the contrary, economic policy is mainly decided through intergovernmental decision-making, ${ }^{335}$ and is thus centered on the role of the European Council (the body representing state governments) to the detriment of the Parliament (representing EU citizens). ${ }^{336}$ In fact, as I mentioned previously, the main explanation for the high degree of judicial involvement in the fiscal domain lies paradoxically in the intergovernmental strategy pursued by the EU member states to respond to the Euro-crisis, based on the European Council and international agreements, rather than on the Community method and EU law. ${ }^{337}$ However, as much as the EU political process is urgently in need of reform, it is unclear to what extent its deficiencies could be cured by greater judicial fiat. An intergovernmental system of governance suffers from major legitimacy gaps. ${ }^{338}$ Since considerations of expertise, voice, and rights indicate that the political process ought to maintain the lead in the fiscal and economic field, reforms should be adopted in order to increase the legitimacy of the EU political process and its capacity to provide a well-functioning arena for democratic decision-making and contestation.

\section{CONCLUSION: REFORMING THE EU POLITICAL PROCESS WITHOUT THE COURTS}

This Article has analyzed the role that courts have so far played in the context of the Euro-crisis. As Part I has explained, the EU institutions and member states have responded to the Euro-crisis by adopting important reforms

333. See Carolene Products, 152 fn. 4. For a comment on the most famous footnote in US constitutional history See also Bruce Ackerman, Beyond the Carolene Products, 98 HARV. L. REV. 713 (1985).

334. See generally LOUIS Fisher, AMERICAN CONSTITUTIONAL LAW. VOlume 1: CONSTITUTIONAL STRUCTURES, SEPARATED POWERS AND FEDERALISM ch. 6 (2005).

335. See also Deirdre Curtin, Challenging Executive Dominance in European Democracy, 77 MODERN L. REV. 1 (2014).

336. See generally PaUl CRAIG \& GRAinNe de BURCA, EU LaW: TeXTS AND Materials $c h$. 20 (2011).

337. See supra text accompanying notes 287-288.

338. See also President, European Parliament, Speech, Fiscal Union without Parliamentary Control is Unacceptable, (Jan. 30, 2012), available at http://www.europarl.europa.eu/thepresident/en/press/press_release_speeches/speeches/sp-2012/sp-2012-january/speeches-2012january-3.html (last visited May 13, 2013) (criticizing the limited involvement of the European Parliament in the governance of the Euro-crisis and emphasizing how a Fiscal Union cannot be legitimate without parliamentary control). 
in the fiscal constitution of the EMU, by strengthening budgetary constraints, introducing new mechanisms of financial stability and setting up a framework of economic adjustments for countries in troubled fiscal conditions. In each of these areas, legal challenges have been raised, and courts have been asked to intervene. As Part II has detailed with reference to high courts' decisions in Estonia, France, Germany, Ireland, Portugal and the EU, courts have been at center stage. National and supranational courts adjudicated issues as varied as the legality of the constitutional changes brought about by the Fiscal Compact, the constitutionality of the ESM Treaty, the admissibility of a simplified amendment process to the TFEU, and the validity of major wage cuts enacted through budgetary legislation implementing domestically the adjustment programs agreed upon by a state government and the troika of international lenders.

As Part III has emphasized, courts throughout the EU have, by and large, validated the measures under review, permitting the reforms to the EU fiscal constitution to go forward. Nevertheless, a qualitative analysis of legal reasoning and judicial rulings has also revealed that courts have grown increasingly dissatisfied with features of the new legal architecture of the EMU, especially measures of financial stability and economic adjustment, and in some recent cases have ended up placing important conditions on the validity of the measures under review or struck them down tout court. As I argued, the main explanation for this development lies in the intergovernmental strategy followed by the EU member states to respond to the Euro-crisis, with the systematic recourse to international agreements adopted outside the EU legal and amenable to domestic judicial review. Paradoxically, intergovernmentalism has created room for judicialization. Had the member states made more use of the "community method" and the ample possibility offered by EU law to enact measures to address the Euro-crisis, the space for judicial interference-and the threat that came with it-would have been largely reduced.

In fact, the paradoxical degree of involvement of national and supranational judiciaries in EMU affairs becomes all the more visible when compared with the role that courts play in the United States. Although the United States is endowed with one of the most powerful and pervasive systems of judicial review worldwide, since at least the 1930 s courts have widely deferred to the political branches in the economic domain, on the understanding that the political process is better placed than the judicial one to answer fundamental budgetary, financial, and economic questions. As I have claimed, however, also in the EMU strong constitutional arguments relating to expertise, voice and rights plead in favor of courts maintaining, or reverting to, a deferent approach vis-à-vis the political branches in the fiscal arena. A lesson that should be learned from the analysis of judicial review of new EMU measures is thus that, in the future, the EU member states should respond to the challenges of the Euro-crisis by adopting ordinary 
legislation in the framework of EU law. ${ }^{339}$ Not only are measures adopted through this procedure more democratically legitimate. They are also more protected from judicial review by courts - save for the scrutiny of the ECJ.

But make no mistake: criticizing judicial interferences in the fiscal domain and stressing the advantages of the ordinary EU law-making process does not imply idealizing it: quite the contrary. As I have repeatedly noted, the EU political process is urgently in need of reform. As acknowledged by the June 2012 report "Towards a Genuine EMU" ${ }^{440}$ written by the President of the European Council, strengthening the legitimacy and accountability of the EU decision-making process in the fiscal field is a necessary step in the future reforms of the EMU.

Decisions on national budgets are at the heart of Europe's parliamentary democracies. Moving towards more integrated fiscal and economic decisionmaking between countries will, therefore, require strong mechanisms for legitimate and accountable joint decision-making. Building public support for European-wide decisions with a far-reaching impact on the everyday lives of citizens is essential." ${ }^{341}$

An echo of the same concerns is also evident in the November 2012 Commission Communication outlining a blueprint for a deep and genuine EMU and opening a debate on future reforms. ${ }^{342}$ Here, it is stated that further proposals for fiscal integration "must be accompanied by commensurate political integration, ensuring democratic legitimacy and accountability." ${ }^{343}$

How these demands for greater legitimacy and accountability should be implemented in institutional terms has been the object of an increasingly lively debate. ${ }^{344}$ A number of proposals have been voiced both by national and EU politicians and by prominent scholars. These proposals range from the suggestion to introduce a direct election of the President of the EU Commission, ${ }^{345}$ or at least to tie the choice of the Commission President to the

339. This lesson apparently has not been learned by policy-makers, as evident by the recent decision of the Ecofin-that the Council of the EU, in the composition grouping the Finance Ministers of the EU member states - to establish a Single Resolution Mechanism for banks within the framework of the Banking Union, partially through an international agreement outside of EU law. See supra text accompanying note 318. See also Council of the EU, Press Release, Dec. 18, 2013 Doc. 17983/13, available at http://www.consilium.europa.eu/uedocs/cms_data/docs/pressdata/ en/ecofin/140193.pdf.

340. President of the European Council, Towards a Genuine EMU, at SN 25/12, (June 25, 2012).

341. Id. at 6 .

342. Commission Communication, A Blueprint for a Deep and Genuine EMU. Launching a European Debate, COM (2012) 777 final.

343. Id. at 11 .

344. See, e.g., Ingolf Pernice ET Al., A Democratic SOlution to the Crisis: Reform Steps towards a Democratically Based ECONOMiC AND FinANCial Constitution for EUROPE (2012).

345. See, e.g., Franck Dekker \& Jared Sonnicksen, The Direct Election of the Commission 
result of the EU Parliament elections ${ }^{346}$ - as recommended recently also in a Commission's Communication ${ }^{347}$ - to the proposal for improving the legitimacy of the President of the European Council, through some forms of indirect popular election. ${ }^{348}$ Discussing the pros and cons of each of these proposals is not the aim of this Article. What is relevant for the purpose of this Article is that this debate is ongoing. In fact, this debate should go on, and it should quickly evolve from mere academic or policy-making discussion into tangible legal reforms. What is also relevant, however, is that each and every of these proposals aims at improving the democratic legitimacy of decision-making, which implies as a primary matter enhancing popular voice "at the level [of government] at which the decisions are taken." 349

Courts play a crucial function in any constitutional regimes, especially in protecting the rights of those individuals who cannot adequately defend themselves through the political process. Yet, the judicial function has limits. In the fiscal arena, the political branches are better placed than courts to take decisions and should therefore be given wide room to decide on how to respond to the Euro-crisis. As the Article has suggested, the political branches can reduce the occasions for judicial interference in the budgetary, financial, and economic domain by adopting, in the future, legal measures in the framework of EU law. Contrary to international agreements (like the ESM Treaty or the Fiscal Compact) which are amenable to domestic judicial review, EU laws (such as the Six Pack, the Two Pack or the EFSM) are only subject to scrutiny by the ECJ. Moreover, because EU laws are adopted through a complex institutional procedure that sees the involvement, and balances the interests, of multiple bodies (including - in most of the cases - the EU Parliament), ${ }^{350}$ adopting legislation in this framework also reduces legitimacy concerns. Yet, it does not

President: A Presidential Approach to Democratizing the European Union, Zei Discussion Paper No. 192 (2009).

346. See, e.g., Miguel Maduro et al., The Euro-Crisis and the Democratic Governance of the Euro: Legal and Political Issues of a Fiscal Crisis, Global Governance Programme Policy Report (2012).

347. Commission Communication, Preparing for the 2013 European Election: Further Enhancing their Democratic and Efficient Conduct, at 6, COM (2013) 126 final.

348. See, e.g., Sergio Fabbrini, After the Euro-Crisis: The President of Europe. A New Paradigm for Increasing Legitimacy and Effectiveness in the EU, EuropEos Commentary No. 12 (2012).

349. President of the European Council, Towards a Genuine EMU, at 8 (Oct. 12, 2012).

350. Note that four out of six of the legal acts adopted in the Six Pack, and both legal acts comprising the Two Pack were enacted pursuant to the co-decision procedure, which involves both the European Parliament and the Council on equal grounds, as co-legislator. The remaining measures of the Six Pack, and the regulation establishing the EFSM, however, were enacted only by the Council, without the active involvement of the European Parliament. See supra notes 16, 17 \& 32. For a criticism of the incomplete involvement of the European Parliament in the governance of EMU and a plea for reform see Miguel Maduro, A New Governance for the European Union and the Euro: Democracy \& Justice, report commissioned by the Constitutional Affairs Committee of the European Parliament PE 462.484 (2012). 
entirely solve them. Responding to the Euro-crisis requires greater democracy and electoral accountability for the fundamental decisions taken in the fiscal field. It would be ironic if courts, by reviewing the future reforms of the constitutional architecture of the EMU, were to prevent this. 